DANIEL BERNARDES CALVO

Estudo das concentrações de proteína C-reativa sérica e liquórica em cães com epilepsia idiopática

São Paulo

2012 


\section{Estudo das concentrações de proteína C-reativa sérica e liquórica em cães com epilepsia idiopática}

Dissertação Apresentada ao Programa de Pós-Graduação em Clínica Veterinária da Faculdade de Medicina Veterinária e Zootecnia da Universidade de São Paulo para obtenção do título de Mestre em Ciências.

\section{Departamento:}

Clínica Médica

Área de Concentração:

Clínica Veterinária

Orientadora:

Profa. Dra. Sílvia Regina Ricci Lucas 
Autorizo a reprodução parcial ou total desta obra, para fins acadêmicos, desde que citada a fonte.

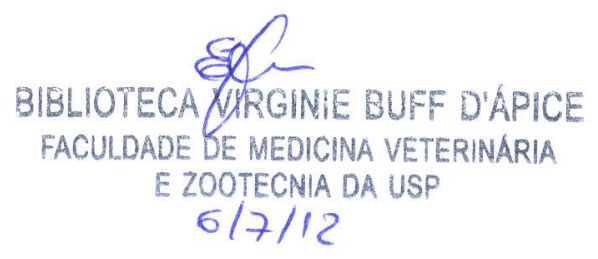

DADOS INTERNACIONAIS DE CATALOGAÇÃO-NA-PUBLICAÇÃO

(Biblioteca Virginie Buff D’Ápice da Faculdade de Medicina Veterinária e Zootecnia da Universidade de São Paulo)

Calvo, Daniel Bernardes

Estudo das concentrações de proteina C-reativa sérica e liquórica em cães com epilepsia idiopática / Daniel Bernardes Calvo. -- 2012

$80 \mathrm{f}$. : il.

Dissertação (Mestrado) - Universidade de São Paulo. Faculdade de Medicina Veterinária e Zootecnia. Departamento de Clínica Médica, São Paulo, 2012

Programa de Pós-Graduação: Clínica Veterinária.

Área de concentração: Clínica Veterinária.

Orientador: Profa. Dra. Sílvia Regina Ricci Lucas.

1. Proteínas. 2. Liquor. 3. Sérica. 4. Convulsão.5. Animais. I. Título. 


\section{Comissão de Ética no uso de animais}

\section{CERTIFICADO}

Certificamos que o Projeto intitulado "Estudo das concentrações de proteína C reativa sérica e liquórica em cães com epilepsia idiopática", protocolado sob o $\mathrm{n}^{\circ}$ 2211/2011, utilizando 40 (quarenta) cães, sob a responsabilidade da Profa. Dra. Silvia Regina Ricci Lucas, está de acordo com os princípios éticos de experimentação animal da "Comissão de Ética no uso de animais" da Faculdade de Medicina Veterinária e Zootecnia da Universidade de São Paulo e foi aprovado em reunião de 22/6/2011.

We certify that the Research "Study of C-reactive protein concentrations in serum and cerebrospinal fluid in dogs with idiopathic epilepsy", protocol number 2211/2011, utilizing 40 (forty) dogs, under the responsibility Profa. Dra. Silvia Regina Ricci Lucas, agree with Ethical Principles in Animal Research adopted by "Ethic Committee in the use of animals" of the School of Veterinary Medicine and Animal Science of University of São Paulo and was approved in the meeting of day $6 / 22 / 2011$.

São Paulo, 18 de junhọ de 2012.

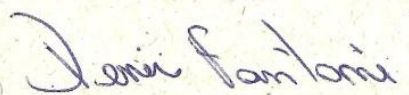

Denise Tabacchi Fantoni

Presidente 


\section{FOLHA DE AVALIAÇÃO}

Autor: CALVO, Daniel Bernardes

Título: Estudo das concentrações de proteína C-reativa sérica e liquórica em cães com epilepsia idiopática.

Dissertação apresentada ao Programa de Pós-Graduação em Clínica Veterinária da Faculdade de Medicina Veterinária e Zootecnia da Universidade de São Paulo para obtenção do título de Mestre em Ciências

Data:

1

\section{Banca Examinadora}

Prof. Dr(a).

Instituição: Julgamento:

Prof. Dr(a). Instituição: Julgamento:

Prof. Dr(a). Instituição: Julgamento: 


\section{DEDICO,}

à Deus, pela minha existência e por todas as coisas boas que ás vezes eu me esqueço de agradecer.

aos meus pais, Tereza e Abílio, meus maiores exemplos de força, dedicação e amor. Jamais conseguirei expressar o quanto sou feliz e grato por ter sido escolhido por Deus para ser o seu filho. Amo vocês

à minha irmã Fernanda Calvo, obrigado pelo apoio, auxílio e principalmente pelo carinho desde sempre!

à minha avó Maria Georgina, sempre rezando por mim, sempre firme nos momentos mais difíceis e grande incentivadora dos meus sonhos.

à minha amiga, namorada, noiva e futura esposa Anne Tramontin, por estar sempre ao meu lado e acima de tudo, pela sua imensa PACIÊNCIA ! Com você descobri o verdadeiro significado do amor, da amizade e do respeito ao próximo. Também não poderia deixar de agradecer minha sogra, Rita por todo carinho e apoio a cada dia.

à minha orientadora Profa. Dra. Sílvia Regina Ricci Lucas não só por ter me orientado e proporcionado a realização deste objetivo profissional, mas por ter acolhido-me de forma carinhosa e paciente durante todo esse período. 


\section{AGRADECIMENTOS}

A todos os professores do Departamento de Clínica Médica de FMVZ-USP, pelo convívio agradável e ensinamentos. Obrigado à Profa. Dra. Sílvia Regina Ricci Lucas, Profa. Dra. Mitika Kuribayashi Hagiwara, Prof. Dr. Archivaldo Reche Júnior, Prof. Dr. Carlos Eduardo Larsson, Profa. Dra. Maria Helena Larsson, Profa. Dra. Márcia Mery Kogika, Profa. Dra. Denise Saretta Schwartz e Prof. Dr. Fernando José Benesi, e Prof. Dr. Wilson Roberto Fernandes e a Profa. Dra. Maria Cláudia Araripe Sucupira.

À Profa. Dra. Ana Carolina Brandão de Campos Fonseca Pinto e a pósgraduanda Carolina de Oliveira Ghirelli, pela realização e análise dos exames tomográficos de todos os pacientes pertencentes a este estudo.

Às médicas veterinárias do Hospital Veterinário da FMVZ-USP: Vera A. B. Fortunato, Bruna Maria Pereira Coelho, Paula Rumy Monteiro, Denise Maria Nunes Simões, Khadine K. Kanayama e Andréa, pela ajuda na triagem dos casos clínicos e troca de conhecimentos durante este período.

Aos funcionários enfermeiros do Hospital Veterinário da FMVZ-USP, particularmente Carlito dos Santos Belau, Milton Gregório dos Santos, Toninho e Jesus, pela colaboração nas coletas e momentos de descontração durante todo o período desde estudo.

Às funcionárias dos diferentes laboratórios do Departamento de Clínica Médica Maria Luíza Franchini, Maria Helena da Silva Pelissari, Marli Elisabete Ferreira de Castro, Cláudia Regina Stricagnolo e Clara S. Mori pela ajuda durante a realização deste trabalho. E à Creide Donizete Costa por nos aturar durante a solicitação dos exames.

Em especial à Samantha Ive Myashiro, por sua imensa paciência e sua dedicação durante a realização das provas laboratoriais e metodologia deste estudo. O que seria de mim sem você?? 
A todos os funcionários da FMVZ pela dedicação em manter esta instituição.

Aos colegas de Pós-graduação: Valter Medeiros, Tatiana, Ana Luiza Nairismagi Alves e Jéssica Soares Garcia por toda ajuda durante o projeto, coletas e muitas risadas. Vocês foram parte fundamental na realização deste trabalho.

Ao meu amigo e colega de pós-graduação Dr. Lucas Campos Sá Rodrigues, boa parte deste trabalho não poderia ser realizado sem a sua colaboração $e$ disponibilidade diante dos contratempos.

Aos Professores e amigos da Anhembi Morumbi Prof. Dr. Ronaldo Lucas, Profa. Dra. Márcia Marques Jericó pelos conselhos durante toda a minha vida profissional e pessoal.

Ao meu professor e amigo Prof. João Pedro de Andrade Neto, obrigado por ter me ensinado o verdadeiro significado de ser veterinário e pelo incentivo durante toda a graduação e pós-graduação na área de neurologia.

A todos os funcionários, enfermeiros e veterinários do hospital veterinário Rebouças em especial : Eduardo Fava Schimidt, Cleonice Martin, Thaís Crema, Cecília Sena, Juliana Santos, Juliana Caldeira, Melissa Sanches, Daniel Baptista, Cristina Satiko, Márcia Melo, Bianca Trevisan, Amanda Godoi.

Aos meus colegas de profissão e amigos fieis: Juliana Ferreiro, Camila Ferreiro, Fabricio Lorenzini, Rafael Magdanelo, Fernando Felipe, Carinne Brunato, Mauricio Flocke, Rafael Rolan. Muito obrigado pelos conselhos, momentos de alegria e troca de conhecimentos proporcionados durante esta etapa. Tenho certeza que nossa amizade é eterna.

Aos residentes do Hospital Veterinário Anhembi Morumbi, Isis , Eros Tanaka, Antonia da Silva, Paula Zagato, Danielle Zanini, Leandro Lopes, Gisele Francine, Fabíola, Marcela, Andréia, Ana Claudia, pela recepção e apoio na etapa final deste sonho. 


\section{RESUMO}

CALVO, D. B. Estudo das concentrações de proteína C-reativa sérica e liquórica em cães com epilepsia idiopática. [Study of C-reactive protein concentrations in serum and cerebrospinal fluid in dogs with idiopathic epilepsy]. 2012. 80 f. Dissertação (Mestrado em Ciência) - Faculdade de Medicina Veterinária e Zootecnia, Universidade de São Paulo, São Paulo, 2012.

A epilepsia compreende um grupo de alterações neurológicas frequentes em humanos e animais, caracterizada pela ocorrência periódica de crises convulsivas. A causa do processo pode ter várias origens sendo necessária a realização de exames complementares para o diagnóstico definitivo. A análise de biomarcadores, em especial as proteínas de fase aguda, como a proteína C-reativa (PCR), auxilia na identificação de doenças neurológicas inflamatórias e infecciosas, já que após serem produzidas pelo fígado conseguem atingir o tecido danificado e ter suas concentrações elevadas rapidamente na circulação. A concentração de PCR está diretamente relacionada à resposta de fase aguda, independentemente da origem ou natureza do estímulo, podendo ser um processo inflamatório, infeccioso ou até mesmo de origem neoplásica. Embora a PCR tenha sido estudada e monitorada em pacientes com as mais variadas doenças, até o momento não foi determinada a presença de PCR no soro e líquor de cães com epilepsia idiopática. O objetivo deste estudo foi avaliar as concentrações de PCR no líquor e soro de cães apresentando epilepsia idiopática e verificar se essa protéina pode ser utilizada como biomarcador para auxiliar no diagnóstico da doença. Para tanto foram compostos três grupos. $O$ primeiro, denominado A, com 23 animais clinicamente normais; o segundo denomindo $B$, composto por 17 cães manifestando convulsão em até 24 horas anteriores ao momento da coleta de mateiral; e o terceiro denominado $\mathrm{C}$, com 16 cães apresentando convulsões de 24 horas até 120 horas antecedendo o momento da coleta do líquor e do soro. Foram mensuradas as proteínas totais séricas e realizadas as eletroforeses, além da análise do líquor e tomografia computadorizada. Animais com alterações estruturais detectadas na tomografia foram excluidos do estudo. As concentrações de PCR séricas foram avaliadas por meio da técnica ELISA utilizando-se kit comercial Tridelta Development Ltd, espécie específico. Além desta avaliação, os grupos $\mathrm{B}$ e C foram alivados quanto à concentração de PCR no 
liquor. Os resultados foram analisados pelo teste de Kruskal Wallis, seguido pelo teste de Dunn, enquanto para eletroforese e análise de PCR no líquor utilizou-se teste $T$ não pareado. Não houve diferença significante em relação à eletroforese de proteínas séricas nos três grupos, assim como não se observaram alterações na análise do líquor nos grupos B e C. As concentrações séricas de PCR em cães normais variaram níveis não detectáveis a $6,36 \mu \mathrm{g} / \mathrm{mL}$, com média de $0,98 \mu \mathrm{g} / \mathrm{mL}$. As concentrações séricas nos animais do grupo $B$ variaram de $1,04 \mu \mathrm{g} / \mathrm{mL}$ a 5,03 $\mu \mathrm{g} / \mathrm{mL}$, com média $2,14 \mu \mathrm{g} / \mathrm{mL}$, enquanto no grupo $C$ as concentrações foram de níveis não detectáveis a $1,9 \mu \mathrm{g} / \mathrm{mL}$ com média $0,51 \mu \mathrm{g} / \mathrm{mL}$. A análise estatística demonstrou diferença significante entre os grupos sendo a média do grupo $B$ superior aos demais $(p=0,0002)$. As concentrações liquóricas de PCR foram muito baixas quando comparadas àquelas observadas em cães com afecções inflamatórias e infecciosas e não foram em sua maioria detectáveis no líquor quando o período entre a convulsão e a coleta foi superior ao período de 24 horas.

Concluiu-se que as convulsões associadas à epilepsia idiopática promovem uma resposta de fase aguda caracterizada pelo aumento de PCR sérica e liquórica nas primeiras 24 horas e que essas concentrações decaem após esse período, podendo estar associadas à liberação de mediadores inflamatórios no SNC e às contrações musculares. Assim sendo, a PCR sérica pode ser utilizada como um biomarcador para diferenciar a epilepsia idiopática de outras causas de convulsão. A técnica ELISA para análise de PCR no líquor, pode se somar às outras análises liquóricas, necessitando ainda de validação.

Palavras-chave: Proteínas. Líquor. Sérica. Convulsão. Animais. 


\section{ABSTRACT}

CALVO, D. B. Study of C-reactive protein concentrations in serum and cerebrospinal fluid in dogs with idiopathic epilepsy. [Estudo das concentrações de proteína C-reativa sérica e liquórica em cães com epilepsia idiopática]. 2012. 80 f. Dissertação (Mestrado em Ciência) - Faculdade de Medicina Veterinária e Zootecnia, Universidade de São Paulo, São Paulo, 2012.

Epilepsy is a group of neurological disorders of humans and animals characterized by recurrent seizures. Epilepsy can have a number of causes and some complementary tests can help with a precise diagnosis. Biomarkers analysis, in special acute protein phase such as $C$ reactive protein (PCR) can help identify inflammatory and infection neurological disease. Acute phase proteins are produced by liver and reach damaged tissue increasing blood concentration. Today studies show that increases in the PCR blood concentration is related to acute inflammatory response independent of mint, whether it is inflammatory, neoplastic or infection. Although PCR has been studied in many diseases, in special neurological disorder followed or not by seizures, until now PCR has not been founded in blood or liquor of dogs with idiopathic epilepsy. The purpose of this study is to evaluate PCR concentration in blood and liquor of patients with idiopathic epilepsy and verify if the protein can be considered a biomarker to help its diagnose. The study has 3 groups. The first named control group A, with 23 healthy animals, the second named B with 17 dogs that have had seizures within $24 \mathrm{~h}$, and the third named $\mathrm{C}$ with 16 dog that have had seizures after 24 to 120 hours from blood or liquor collection. The investigation is based on analyzing total protein and electrophoretic protein profile, liquor analysis and tomography. Patients with structural brain damages detected by tomography were excluded from the study. In the control group PCR concentration were analyzed by ELISA method and kit Tridelta Development Ltd, species specific. In groups B and C were also procedure PCR analyses in liquor sample. The results were analyzed by the Kruskal Wallis test and the Dun test, while electrophorese and PCR of liquor where analyzed by the T test not parried. There was no significant difference in electrophorese in the three groups and there were not found alterations in the liquor analyzes of the groups B and C. PCR blood concentration in healthy dogs vary between not detectable values to $6,36 \mathrm{mcg} / \mathrm{ml}$, with an average of $0,98 \mathrm{mcg} / \mathrm{ml}$. Blood concentrations from animal of group B vary from $1,04 \mathrm{mcg} / \mathrm{ml}$ to 5,03 , with and average of $2,14 \mathrm{mcg} / \mathrm{ml}$. Meanwhile in group $C$ blood concentration values were from not detectable to $1,9 \mathrm{mcg} / \mathrm{dl}$, with an average $0,50 \mathrm{mcg} / \mathrm{ml}$. Statistic analyses show significant difference between groups. Group $B$ average was higher $(p=0,0002)$. PCR liquor concentration was lower to those found on dogs with inflammatory infection diseases and the 
majority were not detectable in the liquor when the sample has been collected after 24 hours from the seizures. It is able to conclude that seizures associated with idiopathic epilepsy promote an acute phase response characterized by an increase of blood and liquor PCR concentrations within 24 hours, and after this period PCR concentrations declined due to the liberation of inflammatory mediators by the CNS and muscle contractions. Therefore blood can be used as a biomarker to differentiate idiopathic epilepsy from other seizures causes. The ELISA technique for PCR liquor analysis still needs to be validated.

Key words: Protein. Cerebrospinal fluid. Serum. Seizure. Animals. 


\section{LISTA DE TABELAS}

Tabela 1 - Analise físico-química do líquor apresentando valores individuais quanto ao aspecto, Leucócitos (Leuc), Proteína total (PT), Glicose (Gli), Aspartato aminotranferase (AST) e Uréia, dos cães avaliados pertencentes ao grupo B - São Paulo - 2012

Tabela 2 - $\quad$ Analise físico-química do líquor apresentando valores individuais quanto ao aspecto, Leucócitos (Leuc), Proteína total (PT), Glicose (Gli), Aspartato aminotransferase (AST) e Uréia, dos cães avaliados pertencentes ao grupo C - São Paulo - 2012

Tabela 3 - Eletroforese de proteínas séricas dos animais do grupo A, apresentando valores individuais de Proteína total (PT), Albumina, Alfa 1 globulina ( $\alpha 1$ ), Alfa 2 globulina ( $\alpha 2)$, Beta globulina $(\beta)$, Gama globulina ( $)$ - São Paulo - 2012

Tabela 4- Eletroforese de proteínas séricas dos animais do grupo B, apresentando valores individuais de Proteína total (PT), Albumina, Alfa 1 globulina ( $\alpha 1$ ), Alfa 2 globulina ( $\alpha 2)$, Beta globulina $(\beta)$, Gama globulina ( ) - São Paulo - 2012

Tabela 5 - Eletroforese de proteínas séricas dos animais do grupo C, apresentando valores individuais de Proteína total (PT), Albumina, Alfa 1 globulina ( $\alpha 1$ ), Alfa 2 globulina ( $\alpha 2)$, Beta globulina $(\beta)$, Gama globulina ( ) - São Paulo - 2012

Tabela 6 - Determinação da Proteína C-reativa sérica do grupo A - São Paulo - 2012

Tabela 7 - Determinação da Proteína C-reativa sérica e liquórica do grupo B - São Paulo - 2012

Tabela 8 - Determinação da Proteína C-reativa sérica e liquórica do grupo C - São Paulo - 2012

Tabela 9 - Variação das concentrações de proteína C-reativa sérica nos grupos A, B e C - São Paulo - 2012 
Tabela 10 - Estatística das concentrações de proteína C-reativa sérica nos grupos A, B e C - São Paulo - 2012

Tabela 11 - Concentrações mínima, máxima e média de proteína C-reativa liquórica nos grupos A, B e C - São Paulo - 2012

Tabela 12 - Comparação das concentrações de proteína C-reativa sérica entre os grupos B e C - São Paulo - 2012

Tabela 13 - Valor mínimo, máximo e médio de beta globulina para cada grupo de estudo - São Paulo - 2012

Tabela 14 - Valor mínimo, máximo e médio de gama globulina para cada grupo de estudo - São Paulo - 2012 


\section{LISTA DE GRÁFICOS}

Gráfico 1 - Concentração individual de proteína C-reativa sérica, de acordo com os grupos experimentais A, B e C - São Paulo - 2012

Gráfico 2 - Concentrações individuais de Proteína C reativa no líquor dos animais dos grupos B e C - São Paulo - 2012 ................................ 


\section{LISTA DE FIGURAS}

Figura 1 - Coleta do LCR - São Paulo - 2012

Figura 2 - Esquematização do teste de ELISA para determinação de proteína C-reativa - São Paulo - 2012 


\section{LISTA DE QUADROS}

Quadro 1 - Composição do grupo A controle - São Paulo - 2012 ................... 34

Quadro 2 - Composição do grupo B - São Paulo - 2012 .............................. 36

Quadro 3 - $\quad$ Composição do grupo C - São Paulo - 2012 ………………...... 38 


\section{LISTA DE APÊNDICES}

Apêndice A Tabela representando hemograma dos animais pertencentes ao grupo A controle. Hemácias (He milhões $\left./ \mathrm{mm}^{3}\right)$, Hematócrito $(\mathrm{Ht}$ / \%), Hemoglobina ( $\mathrm{Hb} / \mathrm{g} / \mathrm{dL}$ ), Volume corpuscular médio (VCM / fl), Hemoglobina corpuscular média (HCM / pg), Concentração de hemoglobina corpuscular média ( $\mathrm{CHCM} / \%)$, Leucócitos (Leuc / $\mathrm{mm}^{3}$ ), Neutrófilos $\left(\mathrm{Neu} / \mathrm{mm}^{3}\right.$ ), Eosinófilos (Eos $/ \mathrm{mm}^{3}$ ), Basófilos (Bas / $\left.\mathrm{mm}^{3}\right)$, Linfócitos Típicos (Linf / $\left.\mathrm{mm}^{3}\right)$, Monócitos $\left(\mathrm{Mon} / \mathrm{mm}^{3}\right)$, Plaquetas (Plaq $\times 10^{3}$ ) - São Paulo - 2012

Apêndice B Tabela representando hemograma dos animais pertencentes ao grupo B. Hemácias (He milhões $\left./ \mathrm{mm}^{3}\right)$, Hematócrito $(\mathrm{Ht} / \%)$, Hemoglobina ( $\mathrm{Hb} / \mathrm{g} / \mathrm{dL})$, Volume corpuscular médio ( $\mathrm{VCM} / \mathrm{fl}$ ), Hemoglobina corpuscular média ( $\mathrm{HCM} / \mathrm{pg})$, Concentração de hemoglobina corpuscular média (CHCM / \%), Leucócitos (Leuc / $\mathrm{mm}^{3}$ ), Neutrófilos (Neu / $\mathrm{mm}^{3}$ ), Eosinófilos (Eos / $\mathrm{mm}^{3}$ ), Basófilos (Bas / $\left.\mathrm{mm}^{3}\right)$, Linfócitos Típicos (Linf / $\left.\mathrm{mm}^{3}\right)$, Monócitos $\left(\mathrm{Mon} / \mathrm{mm}^{3}\right)$, Plaquetas (Plaq $\left.\times 10^{3}\right)$ - São Paulo - 2012

Apêndice $\mathrm{C}$ Tabela representando hemograma dos animais pertencentes ao grupo C. Hemácias (He milhões $/ \mathrm{mm}^{3}$ ), Hematócrito ( $\left.\mathrm{Ht} / \%\right)$, Hemoglobina $(\mathrm{Hb} / \mathrm{g} / \mathrm{dL})$, Volume corpuscular médio ( $\mathrm{VCM} / \mathrm{fl})$, Hemoglobina corpuscular média $(\mathrm{HCM} / \mathrm{pg})$, Concentração de hemoglobina corpuscular média (CHCM / \%), Leucócitos (Leuc / $\mathrm{mm}^{3}$ ), Neutrófilos (Neu / $\mathrm{mm}^{3}$ ), Eosinófilos (Eos / $\mathrm{mm}^{3}$ ), Basófilos (Bas / $\left.\mathrm{mm}^{3}\right)$, Linfócitos Típicos (Linf / $\left.\mathrm{mm}^{3}\right)$, Monócitos $\left(\right.$ Mon / mm³), Plaquetas (Plaq $\times 10^{3}$ ) - São Paulo - 2012

Apêndice $D$ Tabela representando parâmetros bioquímicos dos animais pertencentes ao grupo A controle - São Paulo - 2012

Apêndice $E$ Tabela representando parâmetros bioquímicos dos animais pertencentes ao grupo B - São Paulo - 2012

Apêndice $F \quad$ Tabela representando parâmetros bioquímicos dos animais pertencentes ao grupo C - São Paulo - 2012 


\section{LISTA DE ABREVIATURAS}
AVE Acidente vascular encefálico
CP Ceruloplasmina
DDIV Doença do disco intervertebral
EC Episódios Convulsivos
ECG Eletrocardiograma
EDLS Estenose degenerativa lombossacra
EI Epilepsia idiopática
ELISA Enzime-linked immunosorbent assay
GABA Ácido gama-aminobutírico
GPA Alfa-1-glicoproteína ácida
Hp Haptoglobina
IL-1 Interleucina 1
IL-6 Interleucina 6
IL-8 Interleucina 8
LCR Líquido Cefalorraquidiano
LTH2 Linfócito T helper 2
MARE Meningite arterite responsiva a esteroides
NFkB Fator nuclear kappa B
PCR Proteína C-reativa
PFA Proteínas de fase aguda
RFA Resposta de fase aguda
RM Ressonância magnética
SAA Amilóide A sérica
SN Sistema nervoso
SNC Sistema nervoso central
TC Tomografia computadorizada
TLR Toll like receptors
TNF- $\alpha$ Fator de necrose tumoral alfa
TTR Transtirretina
a Alpha globulina
B Beta globulina
y Gama globulina 


\section{SUMÁRIO}

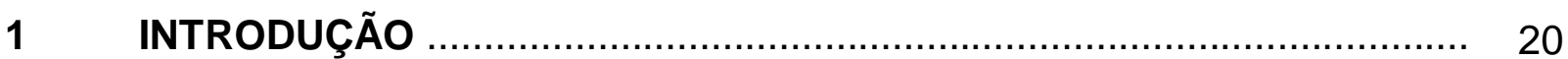

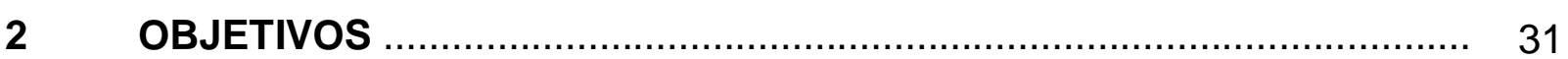

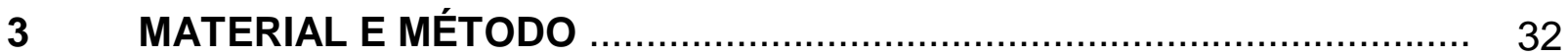

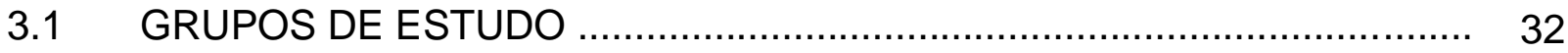

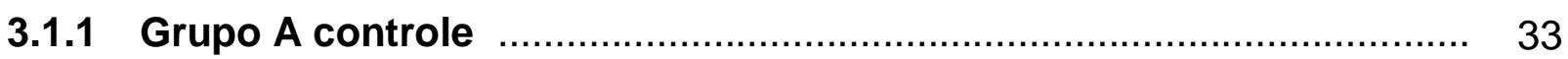

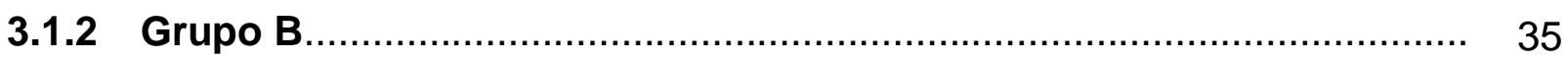

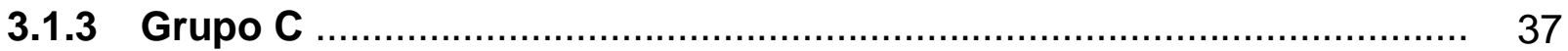

3.2 COLHEITA DO MATERIAL ……............................................. 38

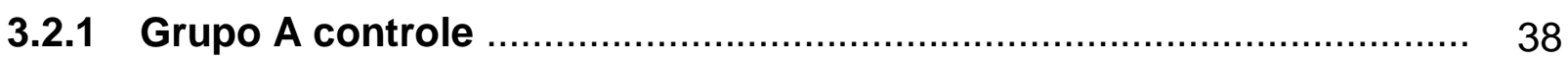

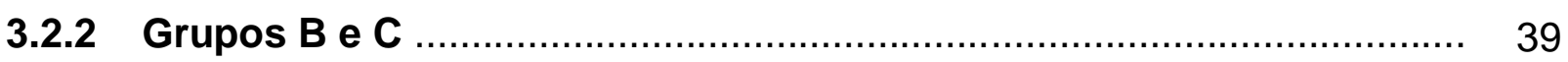

3.3 TÉCNICAS LABORATORIAIS ……......................................... 40

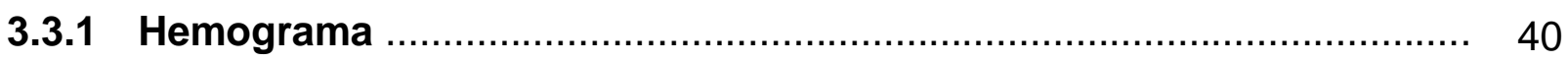

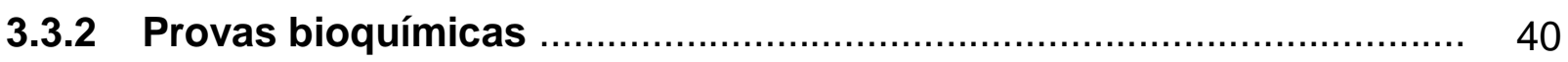

3.3.3 Eletroforese de proteínas séricas .................................................. 41

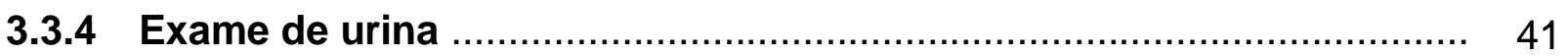

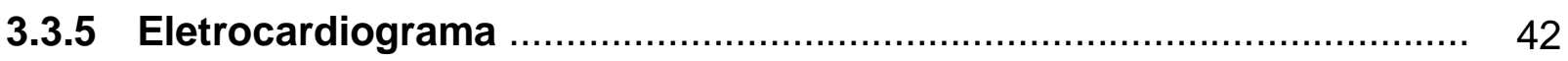

3.3.6 Exame de imagem ............................................................ 42

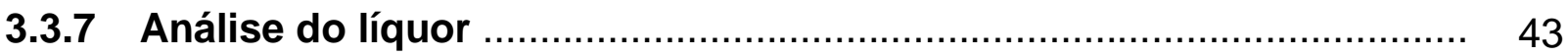

3.3.8 Determinação de proteína C-reativa sérica ......................................... 43

3.3.9 Determinação de proteína C-reativa liquórica ................................... 45

3.4 ANÁLISE ESTATÍSTICA ........................................................... 46

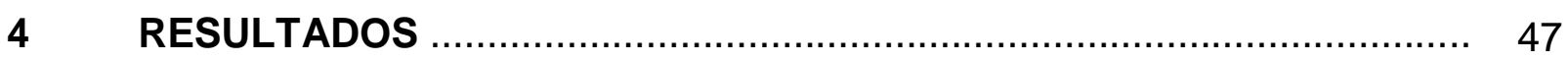

4.1 ANÁLISE LIQUÓRICA GRUPOS B E C .............................................. 47

4.2 ELETROFORESE DE PROTEÍNAS SÉRICAS ..................................... 48

4.3 DETERMINAÇÕES DE PROTEÍNA C-REATIVA SÉRICAS E

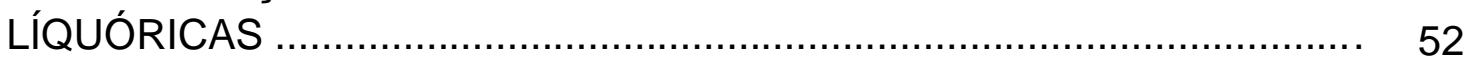

$4.4 \quad$ ANÁLISE ESTATÍSTICA _.......................................................... 55

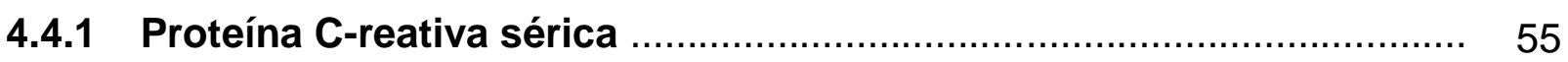

4.4.2 Proteína C-reativa liquórica ........................................................ 56

4.4.3 Eletroforese de proteínas …........................................................... 58

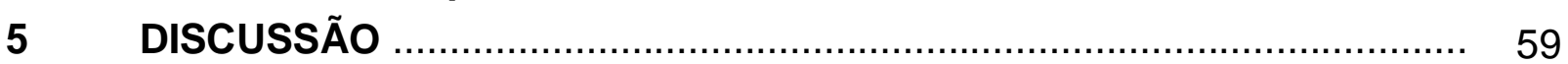

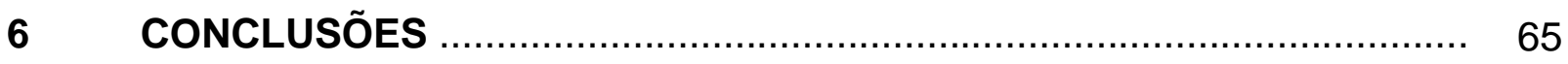

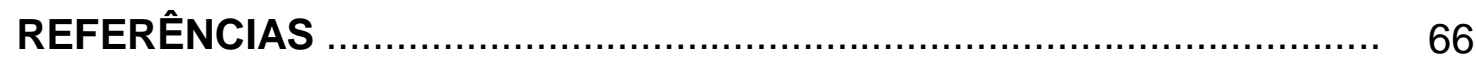




\section{INTRODUÇÃO}

A epilepsia compreende um grupo de alterações neurológicas caracterizadas pela ocorrência periódica de crises de convulsões espontâneas, afetando cerca de cinquenta milhões de pessoas da população mundial (REYNOLD, 2002). Em animais de companhia também é considerada um dos transtornos neurológicos mais frequentes, sendo definida como uma condição neurológica crônica, face à recorrência dos episódios convulsivos (EC) (CHANDLER, 2006).

Os termos convulsão e epilepsia não são sinônimos. O primeiro caracterizase a manifestação clínica da atividade elétrica anormal no cérebro, sendo um evento específico e único, ocorrendo em determinado momento. Já o termo epilepsia referese a convulsões múltiplas, que ocorrem ao longo de um período. Embora não se tenha um padrão bem definido sobre o número mínimo de convulsões ou período de tempo em que ocorrem, a definição clínica adotada é a presença de duas ou mais crises ao longo de um mês ou mais (PODELL et al., 1995; ENGEL, 2006).

A convulsão pode ser dividida em três estágios, sendo eles: pré-ictus, ictus e pós-ictus. $\mathrm{Na}$ fase pré-ictus, período que antecede em dias ou horas o episódio convulsivo, o animal pode apresentar mudanças comportamentais, como: esconderse das pessoas, irritabilidade, nervosismo, agitação ou até mesmo procurar seus proprietários com maior frequência. A fase de ictus é a manifestação da convulsão propriamente dita, com duração e intensidade variável, ocorrendo alteração no tônus muscular ou presença de movimentos involuntários, perda de consciência, sialorreia, acompanhados ou não de micção. Após a crise epilética, o retorno do episódio convulsivo pode ocorrer em segundos ou minutos, podendo variar em alguns casos. Observam-se nesta etapa, alterações comportamentais como inquietação, letargia, desorientação ou amaurose, presentes por alguns minutos ou horas, sendo este período caracterizado como pós-ictus (THOMAS, 2000).

A terminologia para classificar convulsões e epilepsia é complexa e inconsistente, tanto na bibliografia veterinária quanto na humana. Em animais, as convulsões são classificadas de acordo com as manifestações clínicas, perda de consciência e alterações observadas no eletroencefalograma (FARNBACK, 1984; PODELL 2006), sendo denominadas como generalizadas ou focais. A forma 
generalizada, com episódios tônico-clônicos, é a mais comum, acometendo simultaneamente os dois hemisférios cerebrais, já na forma focal, apenas uma determinada região cortical está alterada. Devido à organização do córtex cerebral motor, nas crises focais sempre ocorre o envolvimento dos músculos da face. Além desses dois tipos, focais e generalizadas, observam-se também alguns episódios que se iniciam de forma focal, porém com generalização secundária (THOMAS, 2010).

Quanto à epilepsia, é classificada em reativa, sintomática ou secundária e idiopática (ZIMMERMANN et al., 2009). Na forma reativa ocorre uma agressão ao tecido cerebral normal, sendo suas principais causas as lesões tóxicas (toxinas exógenas), metabólicas (toxinas endógenas) e desequilíbrios eletrolíticos (PODELL, 2004; ZIMMERMANN et al., 2009). Na sintomática ou secundária, as convulsões são decorrentes de uma lesão estrutural, ocasionada por doença intracraniana, podendo apresentar progressão ou não, acometendo tanto cães quanto gatos de qualquer raça ou idade. Pode ser proveniente de encefalites, hidrocefalia ou tumores ou ainda de sequelas provenientes de trauma craniano, hipóxia ou encefalite (PLATT et al., 2002; PARENT, 2004; SMITH et al., 2005; DEWEY et al., 2008; PODELL, 2010).

A epilepsia idiopática (EI) ou de origem primária, também chamada de verdadeira ou hereditária, acomete em média $5 \%$ da população canina (BRAUND, 1994). É a causa mais comum de epilepsia nos cães, sendo definida por uma série de convulsões sem causa identificada, embora suspeita-se de uma possível alteração genética. A maior parte dos cães com El apresenta convulsão entre o primeiro e o quinto ano de idade, embora também, possam ocorrer antes dos seis meses ou após os dez anos de idade (JAGGY et al., 1998; BERENDT et al., 1999; QUESNEL, 2005; PODELL, 2004; CASAL et al., 2006; CHANDLER, 2006; CHANDLER et al., 2008, SCHRIEFI et al., 2008; HÜLSMEYER et al., 2010). Verificase maior predisposição em algumas raças, tais como: Antigo Cão de Pastoreio Inglês, Beagle, Border Collie, Cocker Spaniel Inglês, Cão Pastor Inglês, Dachshund, Irish Wolfhound, Golden Retriever ,Labrador, Keeshond, Pastor Alemão, Pastor Belga Tervuren, Pastor de Berna, Pastor de Shetland e Vizsla. Outras raças e animais sem definição racial podem ser igualmente afetados. Nesses casos o fator genético é uma das possíveis causas, embora não existam estudos publicados até o momento que comprovem essa evidência (MORITA et al., 2005; DE LAHUNTA, 2008; DEWEY et al., 2008; GRUENENFELDER, 2008; HÜLSMEYER et al., 2010). 
No passado, as crises generalizadas tônico-clônicas foram consideradas o tipo mais comum de convulsão em cães com El, não sendo descritas ou aceitas, por alguns autores, a existência de crises focais em pacientes com diagnóstico de origem idiopática. No entanto, pesquisas recentes revelam que cães com El podem ter episódios de crises focais, que podem inclusive, evoluir com generalização e podendo ocorrer mais de um tipo de convulsão (THOMAS, 2010).

Existem quatro mecanismos diferentes envolvidos na origem dos EC de origem idiopática: alteração da membrana neuronal, que pode conduzir a despolarização excessiva; diminuição dos neurotransmissores inibitórios, tal como o ácido gamaminobutírico (GABA), o neurotransmissor inibidor mais potente do sistema nervoso central (SNC); aumento dos neurotransmissores excitatórios, tal como o glutamato; e alteração na concentração extracelular de potássio e cálcio (PLATT; MCDONNELL, 2000; THOMAS, 2010). Não é possível prever o aparecimento das crises, pois sua frequência é variável e ocorrem de maneira espontânea, devido uma variedade de fatores, dentre eles sons altos, luzes coloridas ou mesmo a visita ao veterinário. Porém sabe-se que o período de maior ocorrência é durante o repouso ou o sono (THOMAS, 2010).

$\mathrm{Na}$ abordagem do paciente com histórico de EC, o principal instrumento de diagnóstico disponível para o clínico é o exame neurológico, que fornece informações críticas sobre a função neurológica e principalmente, orienta a localização da lesão. Entretanto este tipo de avaliação é limitada pois não identifica o agente etiológico ou mecanismo fisiopatológico, apenas identifica a alteração no sistema nervoso ( $\mathrm{SN}$ ), direcionando a abordagem para causas extracranianas, como por exemplo alterações metabólicas e tóxicas ou intracranianas como tumores ou acidente vascular encefálico (AVE) e, principalmente, diferencia a epilepsia primária ou idiopática das demais causas, ressaltando-se que, nesta última, não se evidencia qualquer alteração no exame do sistema nervoso.

Para um diagnóstico definitivo e confiável, faz-se necessária a realização de exames complementares como ultrassonografia, exame radiográfico, tomografia computadorizada, ressonância magnética e coleta e análise do líquido cefalorraquidiano (LCR), que são importantes ferramentas para auxiliar a identificar a causa e definir o diagnóstico (PODELL, 1995; THOMAS, 2010). 
O LCR é um produto da filtração do plasma, produzido predominantemente nos plexos coroides, por isso sua composição é diferente daquela do plasma (WAMSLEY, 2004; DI TERLIZZI et al., 2006). O LCR tem como funções a regulação da pressão intracraniana e do ambiente químico do SNC, além do transporte intracerebral de substâncias biológicas ativas, sendo sua análise importante para auxiliar no diagnóstico de neoplasias intracranianas, doenças inflamatórias e infecciosas (DI TERLIZZI et al., 2009). Embora a sua escolha para o diagnóstico seja discutível tendo em vista sua baixa sensibilidade, por vezes a análise do LCR é a única forma de se detectar a presença de uma doença inflamatória ou infecciosa no SNC (LECOUTEUR et al., 2009), fornecendo uma série de informações importantes sobre possíveis alterações nos padrões fisiológicos do tecido nervoso nos pacientes examinados, direcionando a avaliação para um diagnóstico. (WAMSLEY, 2004; DI TERLIZZI et al., 2006).

Para realizar a coleta do LCR, o animal deve estar anestesiado, com o local de punção preparado assepticamente. A coleta ocorre no espaço atlanto-occipital ou caudalmente, no espaço subaracnoide lombar (WAMSLEY, 2004; DI TERLIZZI et al., 2006; THOMAS, 2010). Nos cães, a punção é feita preferencialmente no espaço atlanto-occipital, pois o volume recolhido é maior e a contaminação iatrogênica por sangue é menor. No caso de lesões do SNC, a análise do LCR apresenta maior frequência de alterações quando é colhida caudalmente à lesão (WAMSLEY, 2004; DI TERLIZZI et al., 2009).

Em condições normais, o LCR é um fluído límpido, incolor, que possui viscosidade similar à água, a não ser por altas concentrações de proteína, células inflamatórias ou hemácias, na fase ativa de doenças do sistema nervoso central (TVEDTEN, 1987; THOMAS 2010). As convulsões promovem alterações na composição do LCR, porém a coleta tem que ser realizada após o episódio uma vez que, quanto maior o tempo entre a última crise e a coleta do LCR, menor a probabilidade de alterações liquóricas (GONÇALVES et al., 2010). Em medicina humana, as convulsões têm sido associadas a alterações como pleocitose e aumento dos níveis de proteínas (AMINOFFE; SIMON, 1980; SCHMIDLEY; SIMON, 1981; EDWARDS et al., 1983, PROKESCH et al., 1983), entretanto, a ocorrência dessas anormalidades na análise de LCR após um EC são muito variáveis, tendo 
sido observadas em aproximadamente $30 \%$ dos casos (EDWARDS et al., 1983; PROKESCH et al., 1983).

Em cães, desconhecem-se estas modificações no LCR após a ocorrência de EC de caracter idiopático. Embora pesquisas recentes tenham identificado discretas alterações na contagem celular no LCR após um EC, observou-se uma variação nos resultados obtidos no período posterior e naquele imediatamente à ocorrencia da convulsão, sugerindo uma associação entre o achado de alterações no LCR e o período em que se realiza a coleta (GONÇALVES et al., 2010).

Os mecanismos pelos quais as convulsões podem influenciar a composição fisiológica do LCR não são claros, porém acredita-se que ocorra alteração na barreira hematencefálica e liberação de substâncias quimiotáticas para o LCR durante as crises epilépticas (SCHMIDLEY; SIMON, 1981; EDWARDS et al., 1983). A importância da duração e do número de convulsões na indução de anormalidades pós-ictais no LCR ainda é controversa na medicina humana. Da mesma forma, a associação entre a natureza da crise convulsiva, episódio isolado ou agrupado e a composição do LCR em cães também não foi relatada até 0 momento (GONÇALVES et al., 2010).

Estudos experimentais e clínicos sugerem que exista a ativação de inflamação após EC representado não somente por pleocitose, mas com o aumento dos níveis de citocinas como a interleucina-6 (IL-6) no LCR de pacientes com convulsões tônico-clônicas, sendo estas isoladas ou agrupadas (PELTOLA et al., 2002).

Em outros estudos, a presença de citocinas, quimiocinas e prostaglandinas também é evidenciada rapidamente no cérebro de roedores durante a atividade epilética. Esta observação demonstra que mecanismos imunes podem ser ativados no SNC após episódios convulsivos, favorecendo a realização de novos estudos para investigar mais detalhadamente os mecanismos subjacentes a esta ativação e suas consequências funcionais. O sistema imunológico interage com os demais sistemas e há um envolvimento de mediadores proteicos na modulação da resposta imune. Estes mediadores vêm sendo pesquisados e gradativamente desvendados e manipulados, de modo a serem aplicados em técnicas diagnósticas. Essas descobertas estão possibilitando diagnósticos mais precoces e precisos na rotina clínica. A maior parte dos mediadores de resposta imune é constituída por proteínas, 
consideradas o principal componente dos organismos vivos (CERÓN, 2005; TORRES, 2008).

Esses mediadores proteicos podem estar envolvidos em afecções presentes no organismo em diversas situações como lesões teciduais, traumas, infecções ou doenças imunológicas, que desencadeiam no organismo uma série de reações complexas de modo a impedir a progressão do dano tecidual, isolando e quando possível destruindo o agente etiológico. Esta série complexa de reações é conhecida como resposta de fase aguda (RFA) (GRUYS et al., 1994), e é considerada uma resposta extremamente inespecífica, pois desenvolve-se secundariamente a várias condições que produzem lesão tecidual (CERÓN et al., 2005). É uma reação complexa que envolve efeitos locais e sistêmicos, sendo um deles a alteração na concentração de algumas proteínas plasmáticas, as proteínas de fase aguda (PFA), sintetizadas principalmente pelos hepatócitos.

A lesão tecidual promove a vasodilatação e consequentemente o aumento da permeabilidade vascular, que permite o extravasamento de leucócitos para os sítios do tecido em que ocorre a inflamação. Em estágios iniciais da inflamação, o tipo celular predominante é o neutrófilo, sendo observado também em fases tardias a presença de monócitos e linfócitos, potencializando assim o processo inflamatório. Vários mediadores participam ativamente da resposta inflamatória como as quimiocinas, as quais realizam quimiotaxia de leucócitos, enzimas plasmáticas, como bradicinina e fibrinopeptídeos que aumentam a permeabilidade vascular, a plasminina que ativa proteínas do sistema complemento induzindo a degranulação de mastócitos e consequente liberação de histamina, e opsoninas que induzem a opsonização de microorganismos, facilitando a fagocitose. Outros mediadores importantes estão presentes destacando-se ainda os tromboxanos, prostaglandinas e leucotrienos que participam do processo de vasodilatação associado ao aumento da permeabilidade vascular. Ainda são citadas a ação de citocinas como a IL-1, IL-6 e TNF-a, responsáveis pela expressão de moléculas de adesão e de quimiocinas, facilitando a migração de leucócitos e ainda os efeitos sistêmicos obtidos por meio da produção de PFA (BILATE, 2007).

As citocinas são proteínas de baixo peso molecular, produzidas por diferentes tipos de células do sistema imune quando estas são ativadas por estímulos de origem diversa como agentes infecciosos, neoplasias ou estresse. A principal 
atuação das citocinas é na comunicação entre as células, promovendo a indução ou regulação da resposta imune. Além disso, podem exercer sua ação em órgãos diferentes dos quais foram produzidas, este mecanismo ocorre após a ligação da citocina ao seu receptor específico, expresso na superfície da célula-alvo, desencadeando a transdução de sinais no interior da célula (HEINRICH et al., 1990).

A monitoração da resposta inflamatória ainda é um desafio clínico, pois os sinais da inflamação nem sempre se manifestam clinicamente e muitos dos mediadores citados não estão disponíveis para avaliação na rotina clínica, por isso, a utilização de análises hematológicas e bioquímicas, principalmente a mensuração das PFA, tem sido muito utilizada para diagnosticar doenças inflamatórias (ECKERSALL et al., 2010).

Segundo Jain et al. (2011) as PFA podem ser classificadas de acordo com sua concentração plasmática, quanto ao seu modo de ação e também de acordo com o mecanismo de síntese. A classificação com base na concentração plasmática divide as PFA em negativas e positivas. Após o inicio do processo inflamatório, o fígado responde produzindo um grande número de PFA, ao mesmo tempo a produção de uma série de outras proteínas é reduzida, sendo estas conhecidas como PFA negativas, representadas pela albumina, transferrina, transtiretina, transcortina e a proteína de ligação do retinol (JAIN et al., 2011). Já as proteínas caracterizadas como positivas, apresentam elevação das concentrações séricas na inflamação, como a proteína $C$ reativa $(P C R)$, dímero-D, proteína ligadora de manose, alfa-1 antitripsina, alfa-1 antiquimiotripsina, alfa-2 macroglobulina, fibrinogênio, protrombina, fator VIII, o fator de Von Willebrand, plasminogênio, fatores do complemento, ferritina, amilóide A sérica (SAA), ceruloplasmina (CP), haptoglobina (Hp) e alfa-1 glicoproteína ácida (GPA) (KANEKO et al., 1989; CERÓN et al., 2005; JAIN et al., 2011). As PFA positivas desempenham diversas funções fisiológicas para o sistema imunológico, como destruição ou inibição do crescimento de microrganismos nos quadros de inflamação sistêmica associada ou não a alterações metabólicas, sendo que algumas também são responsáveis pelo feedback negativo sobre a resposta inflamatória (JAIN et al., 2011).

A classificação com base no modo de ação considera a atividade das PFA, dividindo-as em inibidores da protease, por exemplo, alfa-1 antitripsina e alfa-1 antiquimiotripsina; proteínas de coagulação, por exemplo, fibrinogênio e 
protrombina; proteínas do sistema complemento, por exemplo, C2, C3, C4, C5, entre outras; proteínas de transporte, por exemplo, haptoglobina e ceruloplasmina; e outras proteínas, por exemplo, PCR, SAA e GPA. Por ultimo, caracteriza-se a classificação baseada no mecanismo de síntese, sendo que a produção de PFA pode ocorrer de duas formas, a primeira de origem intra-hepática, por meio da estimulação dos hepatócitos e a segunda extra-hepática, na qual o estimulo e a produção são realizados por células epiteliais, endoteliais ou do tecido conjuntivo (JAIN et al., 2011).

Estudos atuais demonstram uma variação nos níveis de PFA em resposta a inflamação nas diferentes espécies de animais. Em bovinos a SAA e a haptoglobina são consideradas as principais PFA, já em suinos a proteína maior de fase aguda (MAP), e em equinos SAA. Os conhecimentos das concentrações séricas e da reatividade de cada proteína são de grande importancia, já que em alguns casos, como por exemplo a haptoglobina em ruminantes, existem concentrações detectáveis mesmo em animais saudáveis e, além disso, existem grande variabilidade e sensibilidade nos diversos métodos utilizados para a determinação destas proteinas considerando as diferentes espécies (MARTÍNEZ-SUBIELA et al., 2001).

As principais PFA descritas em cães são a albumina, pré-albumina ou transtirretina, transferrina, PCR, fibrinogênio, ferritina, haptoglobina, GPA, SAA e ceruloplasmina (JAIN et al., 2011).

A PCR é uma importante PFA tanto em medicina humana como em veterinária, sendo descrita como um marcador muito útil fornecendo informações para o diagnóstico nas alterações inflamatórias, doenças infecciosas, auto-imunes e na resposta ao tratamento. Membro da família pentaxina, com peso moelcular aproximado de 100000 daltons apresenta estrutura evolucional conservada, com cinco subunidades, duas das quais glicosiladas e uma função de calcio ligante dependente (CASPI et al., 1984), a PCR foi descoberta em seres humanos em 1930 (TILLET; FRANCIS, 1930), com base em sua capacidade de aglutinação no soro sanguíneo após precipitação não imunológica com polissacarídeo somático $\mathrm{C}$ de pneumococos spp na presença de cálcio (TILLET; FRANCIS, 1930). Este fator de aglutinação foi identificado como uma proteína em 1941 (ABERNETHY; AVERY, 1940), ano no qual também o anti-soro para PCR humana purificada foi produzido em coelhos (MACLEOD; AVERY, 1941). Pouco tempo depois, a PCR humana foi 
cristalizada (MCCARTY, 1947) e em 1950, o primeiro relatório sobre a aplicabilidade médica da PCR no monitoramento da atividade reumática em pacientes humanos foi descrito (ANDERSON; MCCARTY, 1950).

Em 1960, uma proteína análoga da PCR humana foi investigada em soros sanguíneos de cães na RFA (GOTSCHLICH, 1962; DILLMAN; COLES, 1966), tendo sido isolada em 1970 (RILEY; COLEMAN, 1970) e quantificada em 1972 por meio de anticorpos anti-proteina C-reativa (RILEY; ZONTINE, 1972). A PCR canina não compartilha de antigenicidade com a PCR humana, requerendo testes espécieespecíficos para sua dosagem (YAMAMOTO et al., 1993). Yamamoto et al. (1992) comprovaram sua termolabilidade, com perda de antigenicidade por aquecimento a $70^{\circ} \mathrm{C}$ por 15 minutos. Admite-se que a PCR migre na fração eletroforética de betaglobulinas, juntamente com ferritina, fibrinogênio e transferrina (KANEKO, 1989). Somente a partir da década de 1980 e início dos anos de 1990 é que a PCR canina foi estudada mais minuciosamente, sendo os cães utilizados como modelo para estudo da RFA em humanos devido às semelhanças observadas entre a cinética da PCR humana e canina (CASPI et al., 1984;. CONNER et al., 1988;. ECKERSALL et al., 1988; YAMAMOTO et al., 1992; BURTON et al., 1994).

Após o estímulo inflamatório, são necessárias quatro horas para que as concentrações de PCR comecem a se elevar, tendo o seu valor máximo atingido normalmente em 24 a 48 horas após sua estimulação. A mesma velocidade é observada no declínio de suas concentrações, que ocorre, após a resolução do processo desencadeador ou por meio de um mecanismo de feedback negativo (CASPI et al., 1984; CONNER et al., 1988). O mecanismo de feedback é proveniente da ação de citocinas pró-inflamatórias advindas da resposta de fase aguda, que sofrem um efeito inibitório por uma retroalimentação negativa das PFA. Se o processo se torna crônico, a ação da IL-1 inibe a produção das PFA ou estas continuam sendo produzidas em quantidades menores em relação aos processos agudos (ECKERSALL et al., 2010; JAIN et al., 2011).

Gorter et al, demonstrou em roedores que convulsões podem induzir níveis elevados de mediadores inflamatórios em certas regiões do cérebro e estes estão relacionados à geração e à propagação da atividade epiléptica. (GORTER et al., 2006). Esta resposta consiste no aumento de citocinas inflamatórias tais como a interleucina (IL)-1b, IL-6 e TNF-a na microglia e astrócitos, que são muitas vezes, 
acompanhadas por uma cascata de eventos inflamatórios como a ativação de receptores do tipo "Toll like" (TLR), fator nuclear kappa B (NFkB), sistema complemento, quimiocinas e PFA (JANKOWSKY; PATTERSON, 2001; TURRIN; RIVEST, 2004; VEZZANI; GRANATA, 2005).

Considerando a presença desses mediadores inflamatórios no tecido nervoso, outros estudos foram realizados para verificar possível associação com proteínas de fase aguda e em seres humanos, a PCR sérica foi descrita como um marcador muito útil para o diagnóstico de infecções virais e meningite bacteriana (CARBENELLE, 2009).

A determinação das concentrações de PCR no LCR vem ganhando atenção desde que estudos começaram a realizar a determinações simultâneas e comparativas entre níveis séricos e liquóricos, aumentando assim a sensibilidade no diagnóstico diferencial de afecções de origem exclusivamente neurológica ou sistemicas. (TANKHIWALE, 2001)

Em medicina veterinária, a PCR foi mensurada no LCR de cães auxiliando o diagnóstico de meningite arterite responsiva a esteróides (GANROT, 1973; MURATA, 2004), uma das causas de encefalites inflamatórias mais diagnosticadas em cães. Neste caso, os valores da PCR no LCR foram significativamente mais elevados do que em cães sadios e cães que sofrem de doença do disco intervertebral (DDIV), estenose degenerativa lombossacra (EDLS), El e nos tumores do sistema nervoso central (MARTINEZ-SUBIELA, 2011).

Um fator importante quando se pretende avaliar as concentrações de PCR na rotina clínica é a escolha do metodo laboratorial a ser adotado. A facilidade de execução e o custo são fundamentais para acompanhamento de um caso clínico ou realização de um estudo e devem considerar ainda o fato de que a PCR é específica para cada espécie. Atualmente existem disponiveis alguns métodos específicos para a determinação de PRC, tanto no soro quanto no LCR de animais e seres humanos. O eletroimunoensaio de Caspi et al (1984) foi sucedido pela imunodifusão (CONNER; ECKERSALL, 1988) e "enzime-linked immunosorbent assay" - ELISA (ECKERSALL; CONNER; PARTON, 1989). Com a dificuldade do uso desses procedimentos em laboratórios clínicos, que necessitam técnicas de facíl execução e resultado rápido, Eckersall, Conner e Harvie (1991) desenvolveram um ensaio imunoturbidimétrico. Com o mesmo propósito, Yamamoto et al. (1994), desenvolveram um teste de aglutinação passiva reversa em lâmina, cujos resultados 
não diferiram estatisticamente dos obtidos por ELISA. Os autores, mais tarde, aprimoraram o referido teste adotando capilares para aglutinação os invés de lâminas (TAGATA et al., 1996). Os ensaios mais recentemente descritos para determinar PCR são um teste qualitativo baseado em imunocromatografia utilizando anticorpos contra PCR (MCGROTTY et al., 2004) e um teste imunofluorométrico que, ao contrário dos demais, pode ser executado com amostras de sangue total com anticoagulante (PARRA et al., 2005).

O conhecimento atual da biologia da PCR indica que níveis séricos elevados são condizentes com resposta de fase aguda, independentemente da origem ou natureza do estímulo. A sensibilidade diagnóstica de PCR é facilitada por suas propriedades, ou seja, baixas concentrações em situações fisiológicas em comparação com níveis aumentados durante a resposta de fase aguda, indicando que a PCR seja um marcador de diagnóstico específico pró-inflamatório.

Embora a PCR tenha sido estudada e monitorada em pacientes com disturbios neurológicos, tanto inflamatórios como infecciosos acompanhados ou não de convulsões, até o momento, não foi determinada a presença de PFA, em especial a PCR, no soro e líquor de cães com epilepsia idiopática, ou seja em um processo que, em princípio, cursa sem componentes de infecção ou inflamação. 


\section{OBJETIVOS}

Considerando a PCR como a principal proteína de fase aguda estudada em cães e seu uso cada vez mais frequente como biomarcador em diversas afecções, associada à carência de estudos sobre biomarcadores em cães com afeccções neurológicas, principalmente naqueles casos de animais apresentando somente episódios convulsivos sem causa de base definida, o presente estudo teve como objetivos:

a) Determinar as concentrações séricas de PCR em cães com epilepsia idiopática em dois períodos diferentes (até 24 e mais de 24 horas após a ocorrência da convulsão);

b) Analisar e comparar o perfil eletroforético sérico nesses animais;

c) Avaliar as características físico-químicas e citológicas do líquor;

d) Determinar as concentrações séricas de PCR no líquor pela técnica ELISA;

e) Avaliar se a PCR pode ser utilizada como biomarcador para diferenciar epilepsia idiopática de outras afecções. 


\section{MATERIAL E MÉTODO}

O estudo foi aprovado pela Comissão de Ética no Uso de Animais da Faculdade de Medicina Veterinária e Zootecnia da Universidade de São Paulo protocolado sob número 2211 e aprovado na reunião de 22 de junho de 2011.

\subsection{GRUPOS DE ESTUDO}

Constituíram-se três grupos experimentais, todos compostos por animais da espécie canina, sendo um controle (A) composto por 23 cães clinicamente normais e outros dois grupos compostos por animais apresentando epilepsia idiopática e classificados de acordo com o período em que apresentaram o ultimo episódio convulsivo, sendo eles Grupo B ( 20 cães) e Grupo C (20 cães).

O grupo A controle englobou cães hígidos, provenientes de canis ou residências, com a finalidade de estabelecer os valores que serviriam como controle para análise da proteína C-reativa sérica. Escolheram-se cães clinicamente normais, com vermifugação e imunização (vacinas óctupla/décupla e raiva) atualizadas e sem alterações indicativas de processo inflamatório, infeccioso ou neoplásico ao exame físico. A inclusão no grupo também foi feita com base nos resultados de exames laboratoriais, realizados em todos os animais (hemograma, contagem plaquetária, determinações séricas de uréia, creatinina, fosfatase alcalina, alanina aminotransferase, bilirrubinas, proteínas totais, albumina e globulinas) (Apêndices A e D).

Os animais que compuseram os grupos $\mathrm{B}$ e $\mathrm{C}$ eram provenientes do atendimento dos Serviços de Clínica Médica de Pequenos Animais ou Pronto Atendimento Médico de Pequenos Animais, ambos pertencentes ao Hospital Veterinário da FMVZ-USP ou do Hospital Veterinário Rebouças. Após a anamnese, os animais foram submetidos a exame físico e neurológico e coleta de sangue para exames laboratoriais (hemograma, plaquetometria, determinações séricas de uréia, creatinina, fosfatase alcalina, alanina aminotransferase, bilirrubinas, proteínas totais, 
albumina e globulinas, glicemia, triglicérides, colesterol, urina I) (Apêndices B, C, E e F) .

Nesta primeira etapa, atentou-se à presença de qualquer doença pré existente e a administração de fármacos nos últimos sete dias, sendo este o principal critério de exclusão do grupo. Durante a avaliação, os resultados dos exames laboratoriais foram analisados, além da avaliação cardiológica por meio de eletrocardiograma, desta forma 0 animal já seguia para o procedimento de sedação/anestesia para coleta do líquor e tomografia computadorizada do crânio.

Em um segundo momento, foram analisados todos os exames realizados, tanto os laboratoriais, incluindo a análise do líquor, como os exames de imagem. Diante de resultados compatíveis com os parâmetros de normalidade, os animais foram incluídos nos grupos pré-determinados B e C. Os animais incluídos no grupo B, apresentaram convulsão do tipo "grande mal", generalizada e com duração inferior a cinco minutos nas 24 horas que antecederam a coleta do material, em especial a coleta e análise do líquor. O numero de episódios não foi um fator de eliminação do grupo, sendo adotado apenas o critério do intervalo entre a coleta e o ultimo episódio. Os animais que estavam com sintomas de aumento da pressão intracraniana ou em estado epilético, foram excluídos do estudo. Também foram excluídos os animais que apresentaram alteração em um dos exames de triagem ou que apresentavam sintomas de doença pré-existente, alteração no exame físico e neurológico ou que fizeram ou faziam uso de anti-inflamatórios não esteroidais ou glicocorticoides. Os animais B18, 19 e 20 foram excluídos devido à presença de alteração estrutural detectada no exame tomográfico.

\subsubsection{Casuística Grupo A Controle}

Neste grupo foram avaliados 23 cães, sendo quinze machos e oito fêmeas que compuseram este grupo, entre eles 13 animais sem raça definida e $10 \mathrm{com}$ definição racial. A média de idade foi de três anos e seis meses, com desviopadrão de um ano e nove meses (Quadro 1). 
Quadro 1 - Composição do grupo controle A - São Paulo - 2012

\begin{tabular}{|l|l|l|l|}
\hline Animal & \multicolumn{1}{|c|}{ Raça } & \multicolumn{1}{|c|}{ Idade } & Sexo \\
\hline A1 & Fox terrier & 1 ano & Macho \\
\hline A2 & Rottweiller & 1,5 ano & Macho \\
\hline A3 & SRD & 1 ano & Macho \\
\hline A4 & Yorkshire & 7 anos & Macho \\
\hline A5 & Fox paulistinha & 1 ano & Macho \\
\hline A6 & Fox paulistinha & 2 anos & Fêmea \\
\hline A7 & Bulldog francês & 4 anos & Macho \\
\hline A8 & SRD & 6 anos & Fêmea \\
\hline A9 & SRD & 2 anos & Macho \\
\hline A10 & Poodle & 4 anos & Fêmea \\
\hline A11 & SRD & 5 anos & Fêmea \\
\hline A12 & SRD & 4 anos & Fêmea \\
\hline A13 & Beagle & 6 anos & Fêmea \\
\hline A14 & Poodle & 2 anos & Fêmea \\
\hline A15 & Teckel & 4 anos & Macho \\
\hline A16 & SRD & 4 anos & Fêmea \\
\hline A17 & SRD & 4 anos & Macho \\
\hline A18 & SRD & 4 anos & Macho \\
\hline A19 & SRD & 2 anos & Macho \\
\hline A20 & SRD & 5 anos & Macho \\
\hline A21 & SRD & Macho \\
\hline A22 & SRD & Macho \\
\hline A23 & SRD & \\
\hline
\end{tabular}




\subsubsection{Casuística Grupo B}

Neste grupo foram avaliados 20 animais que apresentaram convulsões em até 24 horas antes do atendimento, sendo que 3 dos animais deste grupo foram excluídos devido a alterações nos exames de imagem. Dos animais mantido no grupo, $35 \%$ não apresentavam definição racial, 18\% eram Cocker inglês, $7 \%$ Poodle, 12\% Teckel, as raças Pastor alemão, Dogue de Bordeaux e Pitbull representaram $6 \%$ cada, totalizando 17 animais. A quantidade de machos foi discretamente superior ao de fêmeas, sendo 59 e $41 \%$ respectivamente e a idade média dos animais deste grupo foi de três anos (desvio padrão de um ano e quatro meses).

Os animais do grupo B apresentaram entre 1 e 6 episódios convulsivos, sendo que destes, três animais apresentaram um episódio, seis animais apresentaram dois e três episódios, um animal apresentou quatro episódios e um animal apresentou seis episódios convulsivos. A média do grupo foi de 2,5 episódios (desvio padrão de 1,23). No quadro 2, encontra-se demonstrado o número de episódios convulsivos e o intervalo entre a convulsão e a coleta do material. 
Quadro 2 - Composição do grupo B - São Paulo - 2012

\begin{tabular}{|c|l|l|l|l|l|}
\hline Animal & & Sexo & Idade & $\begin{array}{l}\text { Numero de } \\
\text { convulsões }\end{array}$ & \multicolumn{1}{|c|}{ Ultimo } \\
Episódio
\end{tabular}




\subsubsection{Casuística Grupo C}

Os animais incluídos no grupo $\mathrm{C}$, apresentaram o mesmo tipo de convulsão que o grupo B, "grande mal", com duração inferior a cinco minutos no período superior a 24 horas e até as 120 horas anteriores ao dia em que se realizou a coleta do material. Foram adotados os mesmos padrões de exclusão que o grupo B. Neste grupo, os animais 17, 18, 19 e 20 foram excluídos devido à presença de alteração estrutural detectada no exame tomográfico. Observa-se que 44\% não apresentavam definição racial, $19 \%$ eram animais das raças Poodle e Teckel, 12\% Fila brasileiro e $6 \%$ da raça Pitbull. O número de machos foi superior ao de fêmeas representando 62 e 38\% respectivamente. A média de idade deste grupo foi de três anos e três meses (desvio padrão de um ano e dois meses).

O numero de convulsões, apresenta variação de 1 a 5 episódios convulsivos, sendo que destes, 4 animais apresentaram 1 episódio, 7 animais apresentam 2 episódios, 3 animais apresentaram 3 episódios, 1 animal apresentou 4 episódios e 1 animal apresentou 5 episódios convulsivos no período superior a 24 horas. A média do grupo foi de 3 episódios (desvio padrão de 4,58). A quadro 3, demonstra a quantidade de episódios convulsivos e o tempo de intervalo entre a convulsão e a coleta do material. 
Quadro 3 - Composição do grupo C - São Paulo - 2012

\begin{tabular}{|c|c|c|c|c|c|}
\hline Animal & Raça & Sexo & Idade & $\begin{array}{l}\text { Numero de } \\
\text { convulsões }\end{array}$ & $\begin{array}{c}\text { Último } \\
\text { Episódio }\end{array}$ \\
\hline C1 & Fila brasileiro & Macho & 2 anos & 1 episódio & 48 horas \\
\hline $\mathrm{C} 2$ & SRD & Macho & 3 anos & 2 episódios & 96 horas \\
\hline C3 & SRD & Macho & 4 anos & 2 episódios & 96 horas \\
\hline C4 & Poodle & Macho & 3 anos & 2 episódios & 48 horas \\
\hline $\mathrm{C} 5$ & Pitbull & Macho & 2 anos & 4 episódios & 120 horas \\
\hline C6 & Teckel & Fêmea & 5 anos & 1 episódio & 48 horas \\
\hline $\mathrm{C7}$ & Fila brasileiro & Fêmea & 2 anos & 5 episódios & 60 horas \\
\hline C8 & Poodle & Fêmea & 6 anos & 2 episódios & 48 horas \\
\hline C9 & Poodle & Macho & 4 anos & 1 episódio & 48 horas \\
\hline C10 & Teckel & Fêmea & 3 anos & 3 episódios & 36 horas \\
\hline C11 & SRD & Macho & 4 anos & 3 episódios & 32 horas \\
\hline C12 & SRD & Macho & 3 anos & 2 episódios & 48 horas \\
\hline C13 & SRD & Macho & 2 anos & 3 episódios & 48 horas \\
\hline C14 & Teckel & Fêmea & 3 anos & 2 episódios & 48 horas \\
\hline C15 & SRD & Fêmea & 4 anos & 2 episódios & 48 horas \\
\hline C16 & SRD & Macho & 2 anos & 1 episódio & 72 horas \\
\hline
\end{tabular}

\subsection{COLHEITA DE MATERIAL}

\subsubsection{Grupo A - Controle}

Os animais do grupo A foram examinados uma única vez, oportunidade em que foi colhido sangue para os exames de triagem necessários à inclusão no estudo. Para a realização dos exames de triagem, as amostras de sangue foram centrifugadas, aliquotadas e encaminhadas imediatamente ao laboratório para processamento. As alíquotas destinadas à determinação de proteína C-reativa foram 
armazenadas em frascos do tipo "eppendorf" âmbar e mantidas sob refrigeração a $-70^{\circ} \mathrm{C}$ para posteriormente processamento.

\subsubsection{Grupo B e C}

Os animais do grupo $\mathrm{B}$ e $\mathrm{C}$ foram atendidos uma única vez, oportunidade em que foi coletado sangue para os exames de triagem necessários, além da separação de uma alíquota para determinação de proteína C-reativa no soro, sendo esta congelada a $-70^{\circ} \mathrm{C}$ imediatamente após centrifugação, para ser processada posteriormente com as demais amostras.

A coleta do LCR foi realizada por meio da punção da cisterna magna como demonstrado na figura 1. Para evitar a movimentação do paciente durante a punção, o LCR foi colhido após procedimento de anestesia geral, com a administração de petidina $4 \mathrm{mg} / \mathrm{Kg}$ por via intramuscular e indução anestésica com propofol intravenoso na dose de $5 \mathrm{mg} / \mathrm{Kg}$. Realizou-se a tricotomia bem como a assepsia do local a ser puncionado. A escolha da agulha para o procedimento foi realizada de acordo com o porte do animal e sempre manuseada com luvas esterilizadas. $O$ líquor foi coletado apenas pelo seu fluir natural, sem aspiração e dividido em duas alíquotas. A primeira para a realização de provas físicas e químicas e a segunda para a dosagem da PCR, sendo esta alíquota armazenada imediatamente após a coleta em frascos do tipo "eppendorf" âmbar e mantida sob refrigeração a $-70^{\circ} \mathrm{C}$ para processamento posterior juntamente com as demais amostras. 
Figura 1 - Coleta do LCR - São Paulo - 2012

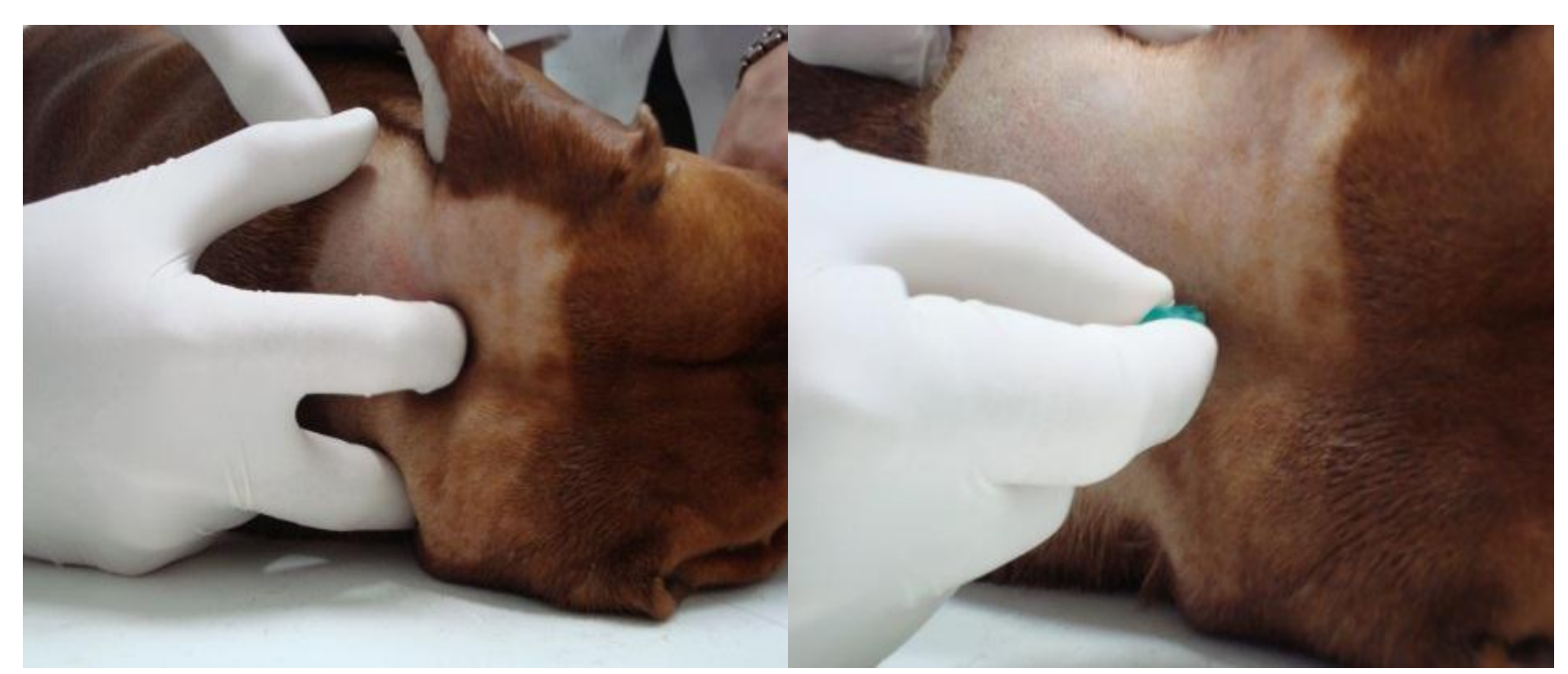

\subsection{TÉCNICAS LABORATORIAIS}

\subsubsection{Hemograma}

Foi utilizado aparelho automático de uso veterinário (ABC Vet Horiba) para contagem de hemácias, leucócitos e plaquetas. Esfregaços de sangue in natura corados por Rosenfeld serviram para executar a contagem diferencial de leucócitos e observar alterações de morfologia das células sanguíneas.

\subsubsection{Provas bioquímicas}

As análises bioquímicas foram feitas em analisador automático (LAB MAX) de acordo com os padrões do Laboratório Clínico do Hospital Veterinário da Faculdade de Medicina Veterinária e Zootecnia da Universidade de São Paulo. Incluíram-se entre as análises as determinações de uréia, creatinina, cálcio, fósforo, alanina-aminotransferase, fosfatase alcalina, bilirrubinas, proteínas totais, albumina e globulinas. 


\subsubsection{Eletroforese de proteínas séricas}

Foi utilizada a técnica de Van Zyl (1966) modificada. Após descongelamento em temperatura ambiente, aplicaram-se as amostras em fitas de acetato de celulose (previamente hidratadas por 10 minutos e enxutas em papel filtro). Cada fita de acetato de celulose de $5,7 \times 14 \mathrm{~cm}$ abrigava 8 amostras de soro. $O$ fracionamento eletroforético foi conduzido em cuba horizontal (BIOSYSTEM ${ }^{\circledR}$ modelo 280) preenchida por tampão TRIS Veronal $\mathrm{pH} 8,8$, usando-se as fitas com as amostras presas a suportes de separação. A corrida eletroforética levou 35 minutos, a 220 $\mathrm{mV}$.

Encerrado o período de corrida, coraram-se as fitas com solução de Ponceau$\mathrm{S}$ (corante vermelho Ponceau-S - $5 \mathrm{~g}$ / ácido tricloroacético - $50 \mathrm{~g} /$ água destilada q.s.p $1000 \mathrm{~mL}$ ) durante 15 minutos. A seguir, foram lavadas com água destilada para retirar o excesso de corante e descoradas em solução de ácido acético a 5\% por 2 vezes (água/ ácido acético/ água/ ácido acético/ água). As fitas, então, foram desidratadas com metanol (por 2 minutos) e imersas em solução diafanizadora (84 $\mathrm{mL}$ de metanol / $16 \mathrm{~mL}$ de ácido acético glacial a $100 \%$ ) por 3 minutos. As fitas eram então esticadas sobre placa de vidro e secas em estufa a $70^{\circ} \mathrm{C}$ durante 7 minutos.

A determinação das frações proteicas foi realizada em programa de computador (MULTI-ANALYST ${ }^{\circledR}$ ), a partir de imagens captadas por "scanner" (BIO-RAD ${ }^{\circledR}$ GS-700).

\subsubsection{Exame de urina}

O exame abrangeu a avaliação físico-química da urina (através de tiras reagentes Combur $\left.^{\circledR} X\right)$ e do sedimento urinário obtido por centrifugação (microscopia óptica). A densidade urinária foi determinada por refratometria. 


\subsubsection{Eletrocardiograma (ECG)}

As avaliações cardiológicas, assim como as realizações e análises dos exames eletrocardiográficos, foram realizados pelo Serviço de Cardiologia do Hospital Veterinário da Faculdade de Medicina Veterinária e Zootecnia da Universidade de São Paulo Para a realização do ECG, utilizou-se o aparelho Ecafix, modelo ECG6, registrando-se as derivações bipolares I, II e III; as unipolares aumentadas aVR, aVL e aVF; e as precordiais rV2 (CV5RL), V2, V4 e V10 em sensibilidade $1 \mathrm{~cm}=1 \mathrm{mV}$ com velocidade $25 \mathrm{~mm} / \mathrm{s}$. Posteriormente, a derivação bipolar II foi registrada novamente, porém em velocidade de $50 \mathrm{~mm} / \mathrm{s}$ e sensibilidade $1 \mathrm{~cm}=1 \mathrm{mV}$.

\subsubsection{Exame de imagem - Tomografia Computadorizada}

O exame tomográfico da cabeça foi realizado no Serviço de Diagnóstico por Imagem do Hospital Veterinário da Faculdade de Medicina Veterinária e Zootecnia da Universidade de São Paulo. O equipamento utilizado foi um tomógrafo helicoidal da marca Toshiba modelo Xpress, e as imagens arquivadas no sistema Pacs. Os animais foram submetidos a anestesia geral com propofol e posicionados em decúbito esternal com os membros torácicos fora da entrada do aparelho ("gantry") para a realização dos cortes transversais da cabeça. Os cortes em reconstrução helicoidal tinham a espessura de $3 \mathrm{~mm}$ com incremento de $3 \mathrm{~mm}$ entre os cortes. As imagens foram obtidas pré e após injeção intravenosa de contraste iodado hidrossolúvel iônico (Urografina $\AA^{\circledR}$ ), no volume aproximado de $1,5 \mathrm{ml} / \mathrm{kg}$ de peso, sendo administrado em bolo. 


\subsubsection{Análise do Líquor}

O aspecto (turbidez) e a coloração do líquor foram avaliados macroscopicamente em tubo transparente. A densidade foi obtida por refratometria e os valores de $\mathrm{pH}$ foram determinados mediante o uso de tiras indicadoras de $\mathrm{pH}$. As contagens globais de células foram realizadas em câmaras de Neubauer e foram preparadas lâminas para avaliação microscópica, sendo estas coradas com corante May Grünwald-Giemsa. As análises foram realizadas imediatamente após a obtenção das amostras, a fim de se evitar a degeneração celular. A glicorraquia e a determinação dos valores de proteínas totais foram determinadas por método colorimétrico com reagente para determinação de glicose (Glucose GOD-PAP, marca DiaSys, Holzheim, Alemanha) e de microconcentração de proteínas (Sensiprot, marca Labtest, Lagoa Santa - MG, Brasil), respectivamente, cujas leituras foram realizadas em aparelho analisador bioquímico.

\subsubsection{Determinação de proteína C-reativa sérica}

Para determinar as concentrações de proteína C-reativa utilizou-se um teste comercial produzido na Irlanda (PHASE ${ }^{\mathrm{TM}}$ RANGE Canine C-reactive Protein Assay, Tridelta Development Limited). Trata-se de um imunoensaio "enzyme-linked immunosorbent assay" - ELISA, realizado em placa, à qual estão acoplados anticorpos contra proteína C-reativa canina. Cada placa continha 96 poços. Como as amostras e os controles ( 6 ao todo) eram processados sempre em duplicata, podiase analisar 42 amostras por placa.

As amostras de soro foram mantidas congeladas a $-70^{\circ} \mathrm{C}$ até o momento da análise. $O$ soro foi diluído na proporção 1:500 (mistura de $10 \mu \mathrm{L}$ de soro homogeneizado a $5 \mathrm{~mL}$ de tampão diluente) em tubos de vidro antes do ensaio, segundo recomendações do fabricante. Na sequência, alíquotas de $100 \mu \mathrm{L}$ do soro diluído foram aplicadas em cada poço e incubadas por 15 minutos a $37^{\circ} \mathrm{C}$. Depois da remoção do excesso de amostra com tampão apropriado em lavadora automática 
(4 ciclos de lavagem), acresciam-se à placa $100 \mu \mathrm{L}$ de conjugado (anticorpo antiproteína C-reativa canina marcado com "Horse Radish Peroxydase" - HRP), sucedendo-se nova incubação por 15 minutos a $37^{\circ} \mathrm{C}$. Após lavagem, os poços receberam $100 \mu \mathrm{L}$ de substrato tetrametilbenzidina (TMB) a fim de haver reação colorimétrica com a peroxidase e a placa foi mantida por 15 minutos, à temperatura ambiente. A solução de bloqueio (100 $\mu \mathrm{L}$ / poço) encerrava a reação (Figura 2).

Figura 2 - Esquematização do teste de ELISA para determinação de proteína C-reativa - São Paulo - 2012

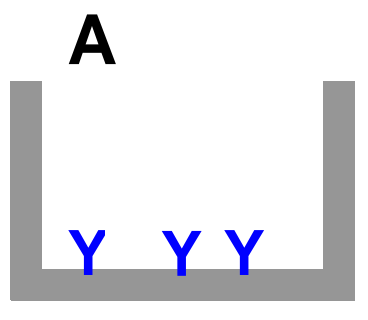

$\mathbf{Y}$

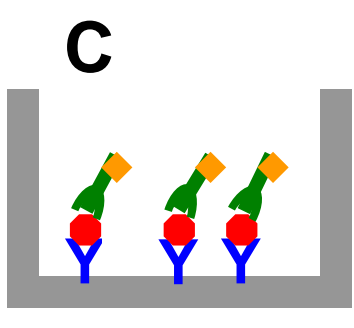

$\mathbf{Y}$

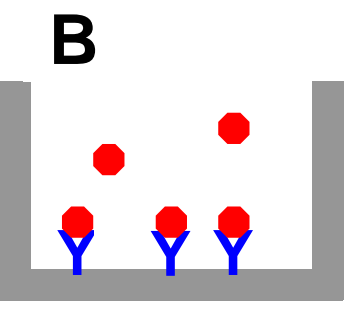

$\mathbf{Y}$

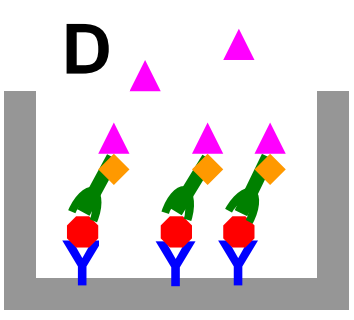

$\mathbf{Y}$

A) Anticorpos anti-proteína C-reativa (em azul) aderidos aos poços da placa; B) Proteína C-reativa da amostra (em vermelho) reagindo com os anticorpos; C) Anticorpos antiproteína C-reativa marcados com peroxidase HRP (em verde e laranja) ligando-se à proteína C-reativa; D) O substrato TMB (lilás) reage com a peroxidase, causando uma reação colorimétrica

Fonte: MERLO, A. Estudo das concentrações séricas de proteína C-reativa e amiloide $A$ em cães com linfoma submetidos a quimioterapia, São Paulo, 2005 
A leitura da absorbância das amostras a $450 \mathrm{~nm}$ foi conduzida em leitora de ELISA Biotek Elx 808 associada ao software de análise Gen5 (Biotek). Obtinha-se uma média entre as duas absorbâncias geradas para cada amostra e cada controle e subtraía-se o valor de absorbância proporcionado pela amostra do controle nulo, o qual não continha proteína C-reativa. Um gráfico de dispersão com as absorbâncias dos controles e as respectivas concentrações de proteína C-reativa (nulo, 7,5 ng/mL, $15 \mathrm{ng} / \mathrm{mL}, 30 \mathrm{ng} / \mathrm{mL}, 60 \mathrm{ng} / \mathrm{mL}$ e $120 \mathrm{ng} / \mathrm{mL}$ ) delineava uma curva de calibração para interpolar as absorbâncias das amostras. Ressalte-se que curvas de calibração foram construídas para cada placa utilizada, não havendo emprego da mesma curva para testes realizados em dias diferentes. Finalmente, para atingir a concentração de proteína C-reativa, multiplicava-se o valor oriundo do gráfico por 500 , ou seja, pelo fator de diluição da amostra. As amostras cuja absorbância excediam o valor do controle máximo sofriam nova diluição e posterior análise. Depois de multiplicar por 500 , fez-se a divisão por 1000 para converter $\mathrm{ng} / \mathrm{mL}$ em $\mu \mathrm{g} / \mathrm{mL}$.

\subsubsection{Determinação de proteína C-reativa liquórica}

Para determinar as concentrações de proteína C-reativa nas amostras de líquor congeladas a $-70{ }^{\circ} \mathrm{C}$, utilizou-se um teste comercial produzido na Irlanda (PHASE ${ }^{\text {TM }}$ RANGE Canine C-reactive Protein Assay, Tridelta Development Limited), o mesmo teste utilizado para a realização da mensuração sérica.

O líquor foi diluído 1:2 (150 $\mu \mathrm{L}$ de líquor em $150 \mu \mathrm{L}$ de tampão de diluição da amostra) em tubos de vidro. Na sequência, alíquotas de $100 \mu \mathrm{L}$ do líquor diluído foram aplicadas em cada poço e incubadas por 15 minutos a $37^{\circ} \mathrm{C}$. Depois da remoção do excesso de amostra com tampão apropriado em lavadora automática (4 ciclos de lavagem), acresciam-se à placa $100 \mu \mathrm{L}$ de conjugado (anticorpo antiproteína C-reativa canina marcado com "Horse Radish Peroxydase" - HRP), sucedendo-se nova incubação por 15 minutos a $37^{\circ} \mathrm{C}$. Após lavagem, os poços receberam $100 \mu \mathrm{L}$ de substrato tetrametilbenzidina (TMB) para promover reação colorimétrica com a peroxidade, por 15 minutos à temperatura ambiente. A solução de bloqueio (100 $\mu \mathrm{L} /$ poço) encerrava a reação. 
A leitura da absorbância das amostras a $450 \mathrm{~nm}$ foi conduzida em leitora de ELISA Biotek Elx 808 associada ao software de análise Gen5 (Biotek). Obtinha-se uma média entre as duas absorbâncias geradas para cada amostra e cada controle e subtraía-se o valor de absorbância proporcionado pela amostra do controle nulo, o qual não continha proteína C-reativa. Um gráfico de dispersão com as absorbâncias dos controles e as respectivas concentrações de proteína C-reativa (nulo, $7,5 \mathrm{ng} / \mathrm{mL}$, $15 \mathrm{ng} / \mathrm{mL}, 30 \mathrm{ng} / \mathrm{mL}, 60 \mathrm{ng} / \mathrm{mL}$ e $120 \mathrm{ng} / \mathrm{mL}$ ) delineava uma curva de calibração para interpolar as absorbâncias das amostras. Ressalte-se que curvas de calibração foram construídas para cada placa utilizada, não havendo emprego da mesma curva para testes realizados em dias diferentes. Finalmente, para atingir a concentração de proteína C-reativa, multiplicava-se o valor oriundo do gráfico pelo fator de diluição da amostra, ou seja por 2 e fez-se nova divisão por 1000 para converter $\mathrm{ng} / \mathrm{mL}$ em $\mu \mathrm{g} / \mathrm{mL}$.

\subsection{ANÁLISE ESTATÍSTICA}

Para comparação das concentrações de Proteína $C$ reativa sérica, beta globulinas e gama globulinas entre os 3 grupos, utilizou-se o teste de Kruskal-Wallis seguido do teste de Dunn. Para comparação entre os valores de PCR no líquor utilizou-se Teste $T$ de Student não pareado. Os testes foram realizados considerando o nível de significância de $5 \%$ e utilizando programa estatístico GraphPad InStat 3.3 


\section{RESULTADOS}

\subsection{ANÁLISE LIQUÓRICA DOS ANIMAIS DOS GRUPOS B E C.}

A análise do líquor foi realizada em todos os animais e verificou-se que nenhum deles apresentou qualquer alteração em sua análise, conforme demonstrado nas tabela 1 e 2 .

Tabela 1 - Analise físico-química do líquor apresentando valores individuais quanto ao aspecto, Leucócitos (Leuc), Proteína total (PT), Glicose (Gli), Aspartato aminotranferase (AST) e Uréia, dos cães avaliados pertencentes ao grupo B - São Paulo - 2012

\begin{tabular}{ccccccc}
\hline Animal & Aspecto & $\begin{array}{c}\text { Leuc } \\
\text { (/fL) }\end{array}$ & $\begin{array}{c}\text { PT } \\
(\mathrm{mg} / \mathrm{dL})\end{array}$ & $\begin{array}{c}\text { Gli } \\
(\mathrm{mg} / \mathrm{dL})\end{array}$ & $\begin{array}{c}\text { AST } \\
(\mathrm{U} / \mathrm{l})\end{array}$ & $\begin{array}{c}\text { Ureia } \\
(\mathrm{mg} / \mathrm{dL})\end{array}$ \\
\hline B1 & Límpido & ausente & 27,0 & 77,0 & 18,6 & 27,6 \\
\hline B2 & Límpido & ausente & 30,0 & 72,5 & 22,1 & 26,0 \\
\hline B3 & Límpido & ausente & 15,0 & 71,1 & 20,5 & 23,0 \\
\hline B4 & Límpido & ausente & 17,4 & 68,0 & 18,0 & 28,2 \\
\hline B5 & Límpido & ausente & 32,0 & 65,0 & 18,9 & 25,9 \\
\hline B6 & Límpido & ausente & 22,3 & 62,2 & 18,6 & 25,7 \\
\hline B7 & Límpido & ausente & 23,5 & 59,3 & 18,2 & 25,6 \\
\hline B8 & Límpido & ausente & 23,0 & 56,5 & 17,9 & 25,5 \\
\hline B9 & Límpido & ausente & 26,0 & 53,6 & 17,5 & 25,4 \\
\hline B10 & Límpido & ausente & 22,4 & 50,8 & 17,2 & 25,3 \\
\hline B11 & Límpido & ausente & 22,2 & 48,0 & 16,9 & 25,1 \\
\hline B12 & Límpido & ausente & 20,0 & 45,1 & 16,5 & 25,0 \\
\hline B13 & Límpido & ausente & 17,0 & 42,3 & 16,2 & 24,9 \\
\hline B14 & Límpido & ausente & 22,0 & 39,4 & 15,8 & 24,8 \\
\hline B15 & Límpido & ausente & 23,5 & 36,6 & 15,5 & 24,7 \\
\hline B16 & Límpido & ausente & 21,0 & 33,8 & 15,2 & 24,5 \\
\hline B17 & Límpido & ausente & 19,0 & 30,9 & 14,8 & 24,4 \\
\hline
\end{tabular}


Tabela 2 - Analise físico-química do líquor apresentando valores individuais quanto ao aspecto, Leucócitos (Leuc), Proteína total (PT), Glicose (Gli), Aspartato aminotransferase (AST) e Uréia, dos cães avaliados pertencentes ao grupo C - São Paulo - 2012

\begin{tabular}{ccccccc} 
Animal & Aspecto & $\begin{array}{c}\text { Leuc } \\
\text { (/fL) }\end{array}$ & $\begin{array}{c}\text { PT } \\
(\mathrm{mg} / \mathrm{dL})\end{array}$ & $\begin{array}{c}\text { Gli } \\
(\mathrm{mg} / \mathrm{d} / \mathrm{L})\end{array}$ & $\begin{array}{c}\text { AST } \\
(\mathrm{U} / \mathrm{l})\end{array}$ & $\begin{array}{c}\text { Ureia } \\
(\mathrm{mg} / \mathrm{dL})\end{array}$ \\
C1 & Límpido & ausente & 15,0 & 69,0 & 16,9 & 29,0 \\
\hline C2 & Límpido & ausente & 21,0 & 67,0 & 18,9 & 31,5 \\
\hline C3 & Límpido & ausente & 18,3 & 70,0 & 19,7 & 27,8 \\
\hline C4 & Límpido & ausente & 19,1 & 58,0 & 18,0 & 25,3 \\
\hline C5 & Límpido & ausente & 30,0 & 65,0 & 18,2 & 26,5 \\
\hline C6 & Límpido & ausente & 29,4 & 63,0 & 16,3 & 27,4 \\
\hline C7 & Límpido & ausente & 28,9 & 68,0 & 18,0 & 23,8 \\
\hline C8 & Límpido & ausente & 16,9 & 59,0 & 17,5 & 23,7 \\
\hline C9 & Límpido & ausente & 23,4 & 54,0 & 18,0 & 22,8 \\
\hline C10 & Límpido & ausente & 31,0 & 60,0 & 17,8 & 21,9 \\
\hline C11 & Límpido & ausente & 20,7 & 57,0 & 16,4 & 21,0 \\
\hline C12 & Límpido & ausente & 17,6 & 48,0 & 19,7 & 20,1 \\
\hline C13 & Límpido & ausente & 27,6 & 42,0 & 16,0 & 19,2 \\
\hline C14 & Límpido & ausente & 25,0 & 51,0 & 15,8 & 18,3 \\
\hline C15 & Límpido & ausente & 16,8 & 47,0 & 16,3 & 17,4 \\
\hline C16 & Límpido & ausente & 31,2 & 46,0 & 17,8 & 16,5 \\
\hline
\end{tabular}

\subsection{ELETROFORESE DE PROTEÍNAS SÉRICAS}

Nas tabelas 3, 4 e 5 são apresentados os resultados das frações eletroforéticas séricas para cada grupo de estudo. Betaglobulinas e Gamaglobulinas foram o principal foco destes resultados, já que a proteína C-reativa pode estar presente em ambas as frações da eletroforese. 
Tabela 3 - Eletroforese de proteínas séricas dos animais do grupo A, apresentando valores individuais de Proteína total (PT), Albumina, Alfa 1 globulina ( $\alpha 1)$, Alfa 2 globulina ( $\alpha 2$ ), Beta globulina ( $\beta$ ), Gama globulina ( $($ ) - São Paulo - 2012

\begin{tabular}{ccccccc} 
Animal & $\begin{array}{c}\text { PT } \\
(\mu \mathrm{g} / \mathrm{mL})\end{array}$ & $\begin{array}{c}\text { Albumina } \\
(\mathrm{g} / \mathrm{dL})\end{array}$ & $\begin{array}{c}\alpha 1 \\
(\mathrm{~g} / \mathrm{dL})\end{array}$ & $\begin{array}{c}\alpha 2 \\
(\mathrm{~g} / \mathrm{dL})\end{array}$ & $\begin{array}{c}\beta \\
(\mathrm{g} / \mathrm{dL})\end{array}$ & $\begin{array}{c}\gamma \\
(\mathrm{g} / \mathrm{dL})\end{array}$ \\
A1 & 7,2 & 3,16 & 0,47 & 0,68 & 0,95 & 1,93 \\
\hline A2 & 6,5 & 3,01 & 0,46 & 0,65 & 0,81 & 1,54 \\
\hline A3 & 7,1 & 3,26 & 0,38 & 0,68 & 0,82 & 1,92 \\
\hline A4 & 6,0 & 3,13 & 0,49 & 0,58 & 0,58 & 1,20 \\
\hline A5 & 6,2 & 3,17 & 0,51 & 0,66 & 0,63 & 1,20 \\
\hline A6 & 6,2 & 3,50 & 0,50 & 0,63 & 0,68 & 1,36 \\
\hline A7 & 5,8 & 3,26 & 0,25 & 0,29 & 0,58 & 1,40 \\
\hline A8 & 6,6 & 2,92 & 0,23 & 0,45 & 0,75 & 2,23 \\
\hline A9 & 6,6 & 3,15 & 0,59 & 0,60 & 1,00 & 1,24 \\
\hline A10 & 6,1 & 2,80 & 0,50 & 0,66 & 0,58 & 1,53 \\
\hline A11 & 5,8 & 2,74 & 0,49 & 0,67 & 0,53 & 1,35 \\
\hline A12 & 6,3 & 3,39 & 0,56 & 0,62 & 0,60 & 1,09 \\
\hline A13 & 6,2 & 3,11 & 0,53 & 0,58 & 0,63 & 1,32 \\
\hline A14 & 6,8 & 3,40 & 0,60 & 0,71 & 0,61 & 1,57 \\
\hline A15 & 7,1 & 3,50 & 0,71 & 0,70 & 0,78 & 1,78 \\
\hline A16 & 6,4 & 3,00 & 0,69 & 0,77 & 0,75 & 1,56 \\
\hline A17 & 6,7 & 3,14 & 0,44 & 0,78 & 0,78 & 1,54 \\
\hline A18 & 6,8 & 3,3 & 0,25 & 0,59 & 0,80 & 2,22 \\
\hline A19 & 6,8 & 3,61 & 0,72 & 0,64 & 0,58 & 1,23 \\
\hline A20 & 6,0 & 3,10 & 0,61 & 0,84 & 0,58 & 1,05 \\
\hline A21 & 6,6 & 3,30 & 0,62 & 0,81 & 0,58 & 1,35 \\
\hline A22 & 6,6 & 3,49 & 0,63 & 0,67 & 0,76 & 1,03 \\
\hline A23 & 6,4 & 3,00 & 0,69 & 0,77 & 0,75 & 1,56 \\
\hline & & & & & & \\
\hline
\end{tabular}


Tabela 4 - Eletroforese de proteínas séricas dos animais do grupo $B$, apresentando valores individuais de Proteína total (PT), Albumina, Alfa 1 globulina ( $\alpha 1$ ), Alfa 2 globulina ( $\alpha 2$ ), Beta globulina ( $\beta$ ), Gama globulina ( $\gamma$ ) - São Paulo - 2012

\begin{tabular}{ccccccc} 
Animal & $\begin{array}{c}\text { PT } \\
(\mu \mathrm{g} / \mathrm{mL})\end{array}$ & $\begin{array}{c}\text { Albumina } \\
(\mathrm{g} / \mathrm{dL})\end{array}$ & $\begin{array}{c}\alpha 1 \\
(\mathrm{~g} / \mathrm{dL})\end{array}$ & $\begin{array}{c}\alpha 2 \\
(\mathrm{~g} / \mathrm{dL})\end{array}$ & $\begin{array}{c}\beta \\
(\mathrm{g} / \mathrm{dL})\end{array}$ & $\begin{array}{c}\gamma \\
(\mathrm{g} / \mathrm{dL})\end{array}$ \\
\hline B1 & 6,8 & 2,90 & 0,55 & 0,66 & 0,99 & 1,67 \\
\hline B2 & 6,2 & 3,48 & 0,37 & 0,76 & 0,72 & 0,85 \\
\hline B3 & 6,5 & 2,19 & 0,23 & 0,58 & 1,39 & 2,08 \\
\hline B4 & 6,0 & 3,00 & 0,28 & 0,67 & 0,72 & 1,31 \\
\hline B5 & 6,2 & 3,14 & 0,26 & 0,54 & 0,68 & 1,55 \\
\hline B6 & 6,2 & 3,00 & 0,34 & 0,91 & 0,59 & 1,34 \\
\hline B7 & 5,8 & 2,89 & 0,33 & 0,66 & 0,68 & 1,21 \\
\hline B8 & 6,6 & 3,18 & 0,39 & 0,95 & 0,58 & 1,48 \\
\hline B9 & 6,4 & 3,09 & 0,38 & 0,92 & 0,56 & 1,43 \\
\hline B10 & 6,2 & 3,09 & 0,36 & 0,71 & 0,73 & 1,29 \\
\hline B11 & 5,8 & 3,15 & 0,59 & 0,60 & 1,00 & 1,24 \\
\hline B12 & 6,1 & 2,80 & 0,50 & 0,66 & 0,58 & 1,53 \\
\hline B13 & 6,0 & 3,07 & 0,39 & 0,69 & 0,41 & 1,41 \\
\hline B14 & 6,3 & 2,74 & 0,34 & 0,68 & 0,85 & 1,66 \\
\hline B15 & 6,2 & 2,90 & 0,55 & 0,57 & 0,80 & 1,35 \\
\hline B16 & 6,0 & 2,84 & 0,40 & 0,64 & 0,73 & 1,35 \\
\hline B17 & 6,4 & 2,30 & 0,36 & 0,64 & 1,28 & 1,79 \\
\hline & & & & & &
\end{tabular}


Tabela 5 - Eletroforese de proteínas séricas dos animais do grupo C, apresentando valores individuais de Proteína total (PT), Albumina, Alfa 1 globulina ( $\alpha 1$ ), Alfa 2 globulina ( $\alpha 2$ ), Beta globulina ( $\beta$ ), Gama globulina ( $\gamma$ ) - São Paulo - 2012

\begin{tabular}{ccccccc} 
Animal & $\begin{array}{c}\text { PT } \\
(\mu \mathrm{g} / \mathrm{mL})\end{array}$ & $\begin{array}{c}\text { Albumina } \\
(\mathrm{g} / \mathrm{dL})\end{array}$ & $\begin{array}{c}\alpha 1 \\
(\mathrm{~g} / \mathrm{dL})\end{array}$ & $\begin{array}{c}\alpha 2 \\
(\mathrm{~g} / \mathrm{dL})\end{array}$ & $\begin{array}{c}\beta \\
(\mathrm{g} / \mathrm{dL})\end{array}$ & $\begin{array}{c}\gamma \\
(\mathrm{g} / \mathrm{dL})\end{array}$ \\
\hline $\mathrm{C} 2$ & 6,5 & 2,78 & 0,52 & 0,63 & 0,95 & 1,59 \\
\hline $\mathrm{C} 3$ & 6,7 & 3,76 & 0,40 & 0,82 & 0,78 & 0,92 \\
\hline $\mathrm{C} 4$ & 6,0 & 2,02 & 0,21 & 0,54 & 1,29 & 1,92 \\
\hline $\mathrm{C} 5$ & 6,3 & 3,15 & 0,30 & 0,70 & 0,75 & 1,38 \\
\hline $\mathrm{C} 6$ & 6,4 & 3,25 & 0,26 & 0,56 & 0,70 & 1,60 \\
\hline $\mathrm{C} 7$ & 5,8 & 3,19 & 0,37 & 0,97 & 0,63 & 1,42 \\
\hline $\mathrm{C} 8$ & 6,5 & 3,14 & 0,38 & 0,93 & 0,57 & 1,46 \\
\hline $\mathrm{C} 9$ & 5,8 & 2,81 & 0,34 & 0,85 & 0,54 & 1,24 \\
\hline $\mathrm{C} 10$ & 6,6 & 2,80 & 0,50 & 0,66 & 0,58 & 1,53 \\
\hline $\mathrm{C} 11$ & 6,4 & 3,28 & 0,42 & 0,74 & 0,44 & 1,50 \\
\hline $\mathrm{C} 12$ & 6,0 & 2,61 & 0,33 & 0,65 & 0,81 & 1,58 \\
\hline $\mathrm{C} 13$ & 5,9 & 2,76 & 0,53 & 0,55 & 0,76 & 1,29 \\
\hline $\mathrm{C} 14$ & 6,8 & 3,22 & 0,46 & 0,73 & 0,83 & 1,53 \\
\hline $\mathrm{C} 15$ & 6,5 & 2,35 & 0,37 & 0,65 & 1,30 & 1,81 \\
\hline $\mathrm{C} 16$ & 6,4 & 2,99 & 0,46 & 0,47 & 0,69 & 1,76 \\
\hline
\end{tabular}


4.3 DETERMINAÇÕES DE PROTEÍNA C-REATIVA LIQUÓRICAS E SÉRICAS.

$\mathrm{Na}$ tabela 6, estão representados os valores séricos de proteína C-reativa, pertencentes ao grupo controle A. Observa-se valor mínimo não detectável e valor máximo de $6,36 \mu \mathrm{g} / \mathrm{mL}$. A média obtida foi de $0,98 \mu \mathrm{g} / \mathrm{mL}$ com desvio padrão de $1,80 \mu \mathrm{g} / \mathrm{mL}$.

Tabela 6 - Determinação da Proteína C-reativa sérica do grupo A - São Paulo - 2012

\begin{tabular}{cc} 
Animal & PCR sérica $(\mu \mathrm{gg} / \mathrm{mL})$ \\
A1 & 1,17 \\
\hline A2 & 1,25 \\
\hline A3 & - \\
\hline A4 & - \\
\hline A5 & 6,36 \\
\hline A6 & 1,96 \\
\hline A7 & - \\
\hline A8 & 1,06 \\
\hline A9 & 5,66 \\
\hline A10 & 2,15 \\
\hline A11 & - \\
\hline A12 & 2,99 \\
\hline A13 & - \\
\hline A14 & - \\
\hline A15 & - \\
\hline A16 & - \\
\hline A17 & - \\
\hline A18 & - \\
\hline A19 & - \\
\hline A20 & - \\
\hline A21 & - \\
\hline A22 & - \\
\hline A23 & - \\
\hline Média & $\mathbf{0 , 9 8 ~}(\boldsymbol{\mu g} / \mathbf{m L})$ \\
\hline D. P. + $/-$ & $\mathbf{1 , 8 0}(\boldsymbol{\mu g} / \mathbf{m L})$ \\
\hline & \\
\hline
\end{tabular}

$(-)$ = Valor não detectável , D. P. = Desvio padrão 
As tabelas 7 e 8, demonstram os valores séricos e liquóricos de proteína $C$ reativa, pertencentes aos grupos B e C. No grupo B, os valores séricos obtidos variaram entre 1,04 a $5,03 \mu \mathrm{g} / \mathrm{mL}$ (média de $2,14 \mu \mathrm{g} / \mathrm{mL}$, desvio padrão de 1,37 $\mu \mathrm{g} / \mathrm{mL}$ ), e para valores liquóricos com mínimo de $3,75 \times 10^{-3} \mu \mathrm{g} / \mathrm{mL}$ e máximo de $43,31 \times 10^{-3} \mathrm{\mu g} / \mathrm{mL}$ (média de 18,66 $\times 10^{-3} \mathrm{\mu g} / \mathrm{mL}$, desvio padrão de $12,09 \times 10^{-3}$ $\mu \mathrm{g} / \mathrm{mL})$.

Tabela 7 - Determinação da Proteína C-reativa sérica e liquórica do grupo B - São Paulo - 2012

\begin{tabular}{|c|c|c|}
\hline Animal & PCR sérica $(\mu \mathrm{g} / \mathrm{mL})$ & $\begin{array}{l}\text { PCR liquórica } \\
\times 10^{-3}(\mu \mathrm{g} / \mathrm{mL})\end{array}$ \\
\hline B1 & 4,27 & 9,39 \\
\hline B2 & 5,03 & 3,75 \\
\hline B3 & 3,78 & 34,67 \\
\hline B4 & 1,92 & 35,81 \\
\hline B5 & 2,79 & 17,82 \\
\hline B6 & 2,19 & 14,52 \\
\hline B7 & 1,07 & 3,75 \\
\hline B8 & 2,12 & 43,31 \\
\hline B9 & 1,05 & 4,30 \\
\hline B10 & 1,07 & 23,41 \\
\hline B11 & 4,27 & 35,53 \\
\hline B12 & 1,05 & 13,53 \\
\hline B13 & 1,62 & 21,04 \\
\hline B14 & 1,04 & 15,01 \\
\hline B15 & 1,05 & 15,12 \\
\hline B16 & 1,06 & 14,15 \\
\hline B17 & 1,04 & 12,14 \\
\hline Média & $2,14(\mu \mathrm{g} / \mathrm{mL})$ & $18,66 \times 10^{-3}(\mu \mathrm{g} / \mathrm{mL})$ \\
\hline D. P. + $/-$ & $1,37(\mu \mathrm{g} / \mathrm{mL})$ & $12,09 \times 10^{-3}(\mu \mathrm{g} / \mathrm{mL})$ \\
\hline
\end{tabular}

D. P. = Desvio padrão 
No grupo $\mathrm{C}$, os valores séricos obtidos variaram entre não detectáveis a $1,98 \mu \mathrm{g} / \mathrm{mL}$ (média de $0,50 \mu \mathrm{g} / \mathrm{mL}$, desvio padrão de $0,63 \mu \mathrm{g} / \mathrm{mL}$ ), e para valores liquóricos mínimo também não detectaveis e máximo de $23,41 \times 10^{-3} \mathrm{\mu g} / \mathrm{mL}$ (média de $1,79 \times 10^{-3} \mu \mathrm{g} / \mathrm{mL}$, desvio padrão de $5,91 \times 10^{-3} \mu \mathrm{g} / \mathrm{mL}$ ).

Tabela 8 - Determinação da Proteína C-reativa sérica e liquórica do grupo C - São Paulo - 2012

\begin{tabular}{ccc} 
Animal & $\begin{array}{c}\text { PCR sérica } \\
(\mu \mathrm{gg} / \mathrm{mL})\end{array}$ & $\begin{array}{c}\text { PCR liquórica } \\
\times 10^{-3}(\mu \mathrm{g} / \mathrm{mL})\end{array}$ \\
C1 & - & - \\
\hline C2 & - & - \\
\hline C3 & - & - \\
\hline C4 & 1,00 & - \\
\hline C5 & 1,00 & - \\
\hline C6 & - & 5,24 \\
\hline C7 & 1,00 & - \\
\hline C8 & - & - \\
\hline C9 & - & 23,41 \\
\hline C10 & 1,02 & - \\
\hline C11 & 1,98 & - \\
\hline C12 & - & - \\
\hline C13 & 1,10 & - \\
\hline C14 & 1,04 & - \\
\hline C15 & - & $\mathbf{1 0 9} \times \mathbf{1 0}^{-3} \mathbf{\mu g} / \mathbf{m L}$ \\
\hline C16 & - & $\mathbf{5 , 9 1 \times \mathbf { 1 0 }} \mathbf{\mu g} / \mathbf{m L}$ \\
\hline Média & $\mathbf{0 , 5 0} \boldsymbol{\mu g} / \mathbf{m L}$ &
\end{tabular}

$(-)=$ Valor não detectável, D. P. = Desvio padrão 


\subsection{ANÁLISE ESTATÍSTICA}

\subsubsection{Proteína $\mathrm{C}$ reativa sérica}

O gráfico 1 resume as concentrações individuais de proteína C-reativa para cada grupo, mostrando concentrações superiores no grupo $\mathrm{B}$, quando comparado com os grupos $\mathrm{A}$ e $\mathrm{C}$.

Gráfico 1 - Concentração individual de proteína C-reativa sérica, de acordo com os grupos experimentais A, B e C - São Paulo - 2012

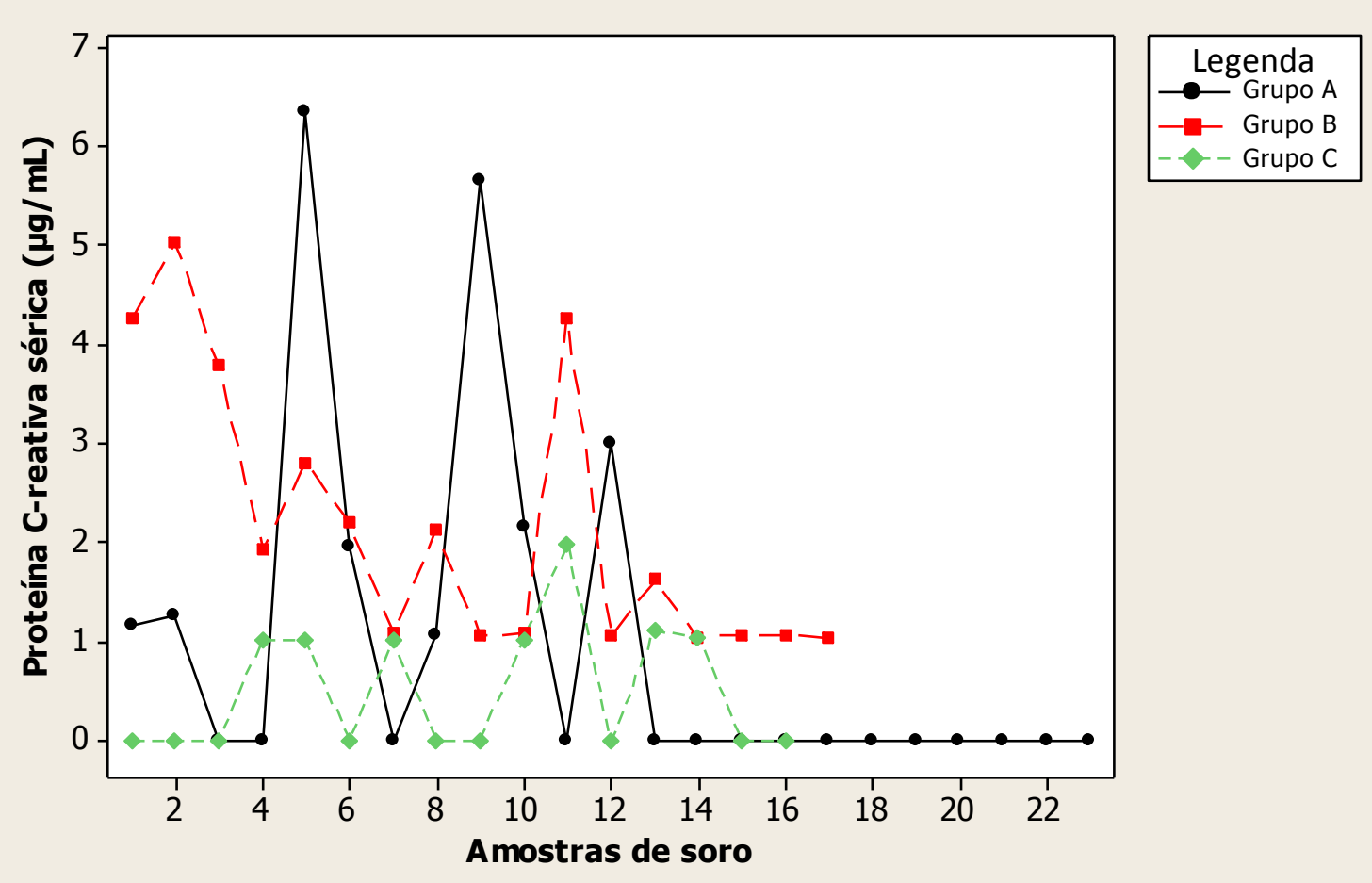

Para análise comparativa dos níveis de proteína C-reativa sérica realizou-se análise de variância não paramétrica seguida pelo teste de Dunn (Tabela 9). 
Tabela 9 - Variação das concentrações de proteína C-reativa sérica nos grupos A, B e C - São Paulo - 2012

\begin{tabular}{ccccc} 
Grupo & $\begin{array}{c}\text { Número } \\
\text { amostras }\end{array}$ & $\begin{array}{c}\text { Mínima } \\
(\mu \mathrm{g} / \mathrm{mL})\end{array}$ & $\begin{array}{c}\text { Máxima } \\
(\mu \mathrm{g} / \mathrm{mL})\end{array}$ & $\begin{array}{c}\text { Média } \\
(\mu \mathrm{g} / \mathrm{mL})\end{array}$ \\
\hline A & 23 & 0,000 & 6,365 & 0,984 \\
B & 17 & 1,040 & 5,033 & 2,146 \\
C & 16 & 0,000 & 2,726 & 0,681 \\
\hline
\end{tabular}

As concentrações observadas no grupo B foram superiores aos grupos A e C. $(p=0,0002)$. Foram conduzidas as comparações múltiplas de Dunn para os níveis de proteína C-reativa entre os grupos (Tabela 10) mostrando que as concentrações séricas de proteína $\mathrm{C}$ reativa no grupo $\mathrm{C}$ foram similares às do Controle $\mathrm{A}$.

Tabela 10 - Estatística das concentrações de proteína C-reativa sérica nos grupos A, B e C - São Paulo - 2012

\begin{tabular}{lcc} 
Grupo & Diferença da média & $\mathrm{p}$ \\
\hline $\mathrm{A} \times \mathrm{B}$ & $-17,422$ & $\mathrm{p}<0,01$ \\
$\mathrm{~A} \times \mathrm{C}$ & 3,446 & $\mathrm{p}>0,05$ \\
$\mathrm{~B} \times \mathrm{C}$ & 20,868 & $\mathrm{p}<0,001$ \\
\hline
\end{tabular}

\subsubsection{Proteína $\mathrm{C}$ reativa liquórica}

O gráfico 2, resume as concentrações individuais de proteína C-reativa liquórica nos grupos B e C, mostrando concentrações superiores no grupo B, quando comparadas com o grupo C. Apenas um dos cães pertencentes ao grupo C (Amostra 10), apresentou valor de proteína C-reativa superior ao restante do grupo. 
Gráfico 2 - Concentrações individuais de Proteína C reativa no líquor dos animais dos grupos B e C - São Paulo - 2012

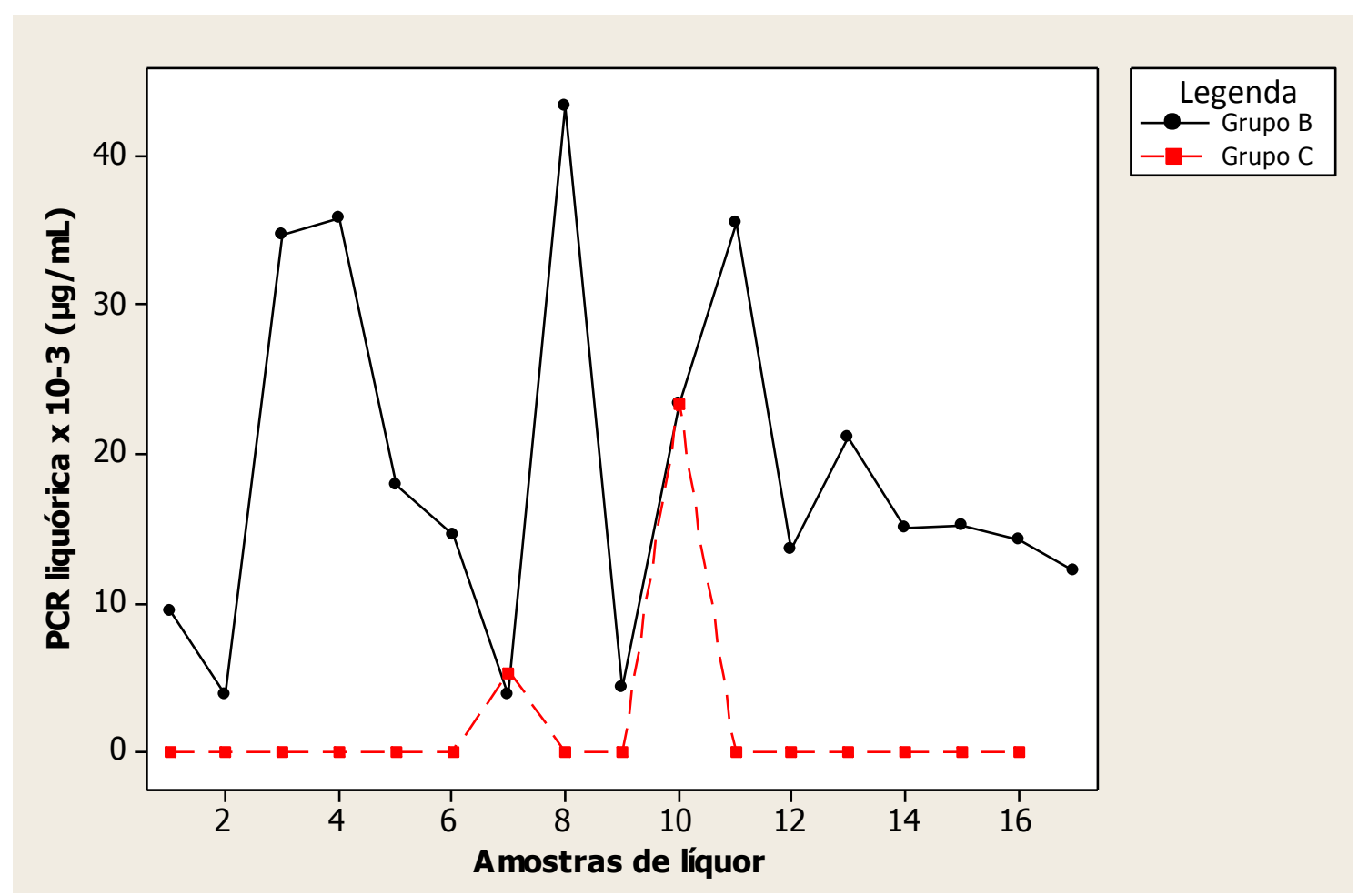

As concentrações médias do grupo $B$ foram superiores ao grupo $C(p<0.0001)$ (Tabela 11).

Tabela 11 - Concentrações mínima, máxima e média de proteína C-reativa liquórica nos grupos A, B e C - São Paulo - 2012

\begin{tabular}{ccccc} 
Grupo & N. amostras & $\begin{array}{c}\text { Mínima } \\
(\mu \mathrm{g} / \mathrm{mL})\end{array}$ & $\begin{array}{c}\text { Máxima } \\
(\mu \mathrm{g} / \mathrm{mL})\end{array}$ & $\begin{array}{c}\text { Média } \\
(\mu \mathrm{g} / \mathrm{mL})\end{array}$ \\
\hline B & 17 & 0,0037 & 0,04331 & 2,146 \\
C & 16 & 0 & 0,02341 & 0,681 \\
\hline
\end{tabular}

Observa-se que o valor da amostra na tabela 12, referente ao grupo $B$ foi detectável com valor médio de 0,01502 , com $p=<0.0001$, considerado extremamente significante. 
Tabela 12 - Comparação das concentrações de proteína C-reativa sérica entre os grupos B e C - São Paulo - 2012

\begin{tabular}{ccccc} 
Grupo & N. amostras & Desvio padrão & Erro padrão & Média \\
\hline B & 17 & 0,01209 & 0,002933 & 0,01502 \\
C & 16 & 0,00591 & 0,001478 & 0 \\
\hline
\end{tabular}

\subsubsection{Eletroforese de proteínas séricas}

As frações beta globulina e gama globulina, foram comparadas com todos os grupos de estudo através do teste Kruskal-Wallis como observado nas tabelas 13 e 14, onde não demonstrou significância para valores de beta globulinas ( $p=$ 0.7724 ) e para gama globulinas $(p=0,6378)$.

Tabela 13 - Valor mínimo, máximo e médio de beta globulina para cada grupo de estudo - São Paulo - 2012

\begin{tabular}{cccc} 
Grupo & Mínima $(\mathrm{g} / \mathrm{dL})$ & Máxima $(\mathrm{g} / \mathrm{dL})$ & Média $(\mathrm{g} / \mathrm{dL})$ \\
\hline A & 0,5300 & 1,000 & 0,6800 \\
B & 0,4100 & 1,390 & 0,7200 \\
C & 0,4400 & 1,300 & 0,7250 \\
\hline
\end{tabular}

Tabela 14 - Valor mínimo, máximo e médio de gama globulina para cada grupo de estudo - São Paulo - 2012

\begin{tabular}{cccc} 
Grupo & Mínima $(\mathrm{g} / \mathrm{dL})$ & Máxima $(\mathrm{g} / \mathrm{dL})$ & Média $(\mathrm{g} / \mathrm{dL})$ \\
\hline A & 1,030 & 2,230 & 1,360 \\
B & 0,850 & 2,080 & 1,410 \\
C & 0,920 & 1,920 & 1,515 \\
\hline
\end{tabular}




\section{DISCUSSÃO}

A existência de publicações em medicina humana indicando associação de episódios convulsivos com o estímulo na liberação de citocinas pró-inflamatórias como a IL-6 e a produção de proteínas de fase aguda, motivaram a execução deste estudo. Em medicina veterinária especificamente, o enfoque das pesquisas tem se voltado à proteína C-reativa, tanto para diagnóstico quanto para o monitoramento de doenças infecciosas e processos inflamatórios de maneira geral. A bibliografia compilada não apresentou estudos com delineamento e objetivos semelhantes aos aqui apresentados, já que nos estudos compulsados, os pesquisadores atentaramse à mensuração de proteínas de fase aguda nos processos inflamatórios e infecciosos independentemente da ocorrência ou não de episódios convulsivos e principalmente, sem considerar a proximidade do momento em que ocorreu a convulsão e a coleta do material. Assim, dificuldades e questionamentos advindos refletem em parte, a carência de informações vinculadas ao tema.

No presente estudo a idade média dos animais apresentando epilepsia idiopática foi de 3 anos, com idade mínima de 1 ano e máxima de 6 anos. Estes achados concordam com os descritos por Thomas (2010), que refere a ocorrência de convulsões por epilepsia idiopática entre 1 e 6 anos de idade, porém, podendo manifestar-se em faixa mais ampla, de 1 a 10 anos. A mesma faixa etária também foi relatada por Podell (2004); Gruenenfelder (2008); Dewey e Thomas (2008) e Zimmermann et al. (2009) que em estudo com 113 cães com epilepsia idiopática observou média de 4,5 anos, com idade mínima de 1 ano e máxima de 6 anos.

A predisposição racial do grupo estudado também foi um dado importante, uma vez que 20 animais eram de raça pura e 13 animais sem definição racial. De acordo com a maioria dos autores, a predisposição para a ocorrência de epilepsia idiopática é maior em animais com raça definida, em especial as raças Beagle, Pastor Alemão, Labrador Retriever, Golden Retriever, Pastor Belga Tervueren, Braco Húngaro, Cão da Montanha de Berna, Keeshond, Springer Spaniel Inglês, Wolfhound Irlandês (MORITA et al., 2005; DE LAHUNTA, 2008; DEWEY et al., 2008; GRUENENFELDER, 2008), entretanto, outras raças e animais sem raça definida também são relacionados nos estudos desses mesmos autores. Entretanto, no 
estudo de Zimmermann et al. (2009) com 113 cães, todos apresentavam definição racial. Esses dados devem ser analisados cuidadosamente, considerando o perfil dos animais criados em determinados países e também a variação na preferência por determinadas raças que ocorre ao longo do tempo. Assim, o perfil observado no estudo é, de fato, o mais esperado em nosso meio, devido a alta frequência de cruzamentos raciais e grande número de animais sem definição racial. Predisposição sexual também foi observada neste estudo, sendo que cães machos foram mais afetados do que fêmeas, achados similares são citados nas revisões bibliográficas realizadas por Berendt et al. (2008) e De Lahunta (2008), embora não exista uma explicação reconhecida para o fato.

As concentrações séricas de proteína $C$ reativa obtidas no grupo controle, sem ocorrência de episódios convulsivos, com média de $0,98 \mu \mathrm{g} / \mathrm{mL}$, mínima não detectável e máxima de $6,36 \mu \mathrm{g} / \mathrm{mL}$, foram inferiores àquelas relatadas em literatura. Burton et al. (1994) encontraram média de proteína $C$ reativa de $12 \mu \mathrm{g} / \mathrm{mL}$ (desvio padrão de 4,8 $\mu \mathrm{g} / \mathrm{mL}$ com mínima de $5,9 \mu \mathrm{g} / \mathrm{mL}$ e máxima de $28,7 \mu \mathrm{g} / \mathrm{mL}$ ) em um grupo de 44 cães saudáveis, por meio de ensaio imunoturbidimétrico. Utilizando a técnica de ELISA, a mesma adotada neste estudo, Yamamoto et al. (1993) registraram níveis de proteína $C$ reativa variando de 2,4 a $30,04 \mu \mathrm{g} / \mathrm{mL}$ (média de 8,43 e desvio padrão de $4,86 \mu \mathrm{g} / \mathrm{mL}$ ) em 66 cães. Yamamoto et al. (1994) ratificaram as observações do ano anterior em um grupo de 150 animais, ao obter níveis médios de 7,2 $\mu \mathrm{g} / \mathrm{mL}$ (desvio padrão de 4,5 e faixa de 0,6 a $30 \mu \mathrm{g} / \mathrm{mL}$ ).

As concentrações verificadas por Otabe et al. (1998), que acompanharam as variações de proteína $C$ reativa em 10 cães da raça Beagle, em um período de 24 horas e durante 4 semanas, mostraram média de $3,65 \mu \mathrm{g} / \mathrm{mL}$ (desvio padrão de 1,4 e faixa de 0,8 a $22,6 \mu \mathrm{g} / \mathrm{mL}$ ). Nota-se que nas abordagens com maior numero de indivíduos (BURTON et al., 1994; YAMAMOTO et al., 1993; YAMAMOTO et al., 1994) as médias da proteína mostraram-se superiores, com faixas de variação mais amplas e desvios padrão elevados. Uma explicação cabível é que existam animais clinicamente normais com concentrações fisiológicas elevadas de proteína $\mathrm{C}$ reativa. Os valores obtidos por Merlo (2005) nos animais do grupo controle foram os que mais se aproximaram daqueles obtidos neste estudo, com concentrações séricas médias de 2,77 $\mu \mathrm{g} / \mathrm{mL}$ (desvio padrão de 2,02 $\mu \mathrm{g} / \mathrm{mL}$ com variação de 0,56 a 7,1 $\mu \mathrm{g} / \mathrm{mL}$ ). Em todos os estudos revisados, os valores obtidos em animais normais 
apresentaram grande oscilação, podendo essa variação ser atribuída a diferenças de armazenamento, aos profissionais envolvidos na execução e equipamentos utilizados em cada estudo, além da própria técnica. Os valores do grupo controle obtidos por Merlo (2005) seguiram os mesmos padrões do presente estudo. Este fato pode justificar a proximidade dos valores de animais normais observados nos dois estudos e indicar que é necessário que cada laboratório estabeleça seus valores de referência.

A avaliação da proteína $C$ reativa sérica no grupo $B$ apresentou valores acima da média quando comparados aos valores obtidos nos grupos controle e $\mathrm{C}$. Um dos cães avaliados no grupo $\mathrm{C}$ apresentou concentração similar à média do grupo $\mathrm{B} \mathrm{e}$ superior aos demais do grupo C. Provavelmente este fato ocorreu porque este animal apresentou episódios convulsivos no período de 32 horas anteriores à coleta, intervalo muito próximo ao preconizado para o grupo $B$, no qual se realizou a coleta nas 24 horas que sucederam ao episódio convulsivo, portanto, apenas e tão somente 8 horas a mais. Excluindo esse cão, o grupo $C$ manteve a média e valores máximos similares aos obtidos no grupo controle, fato esse explicado pela redução gradativa dos níveis de proteína $C$ reativa após a crise convulsiva. Esse achado é condizente com o comportamento biológico da proteína $C$ reativa relatado na literatura, cujas concentrações máximas são atingidas em 24 a 48 horas após 0 estimulo, acompanhada por redução gradual promovida por feedback negativo (JAIN et al., 2011). Esse aumento de baixa magnitude também justifica porque não ocorreram alterações na eletroforese de proteínas séricas entre os grupos.

O número de episódios convulsivos variou de 1 a 6 em ambos os grupos estudados, sendo que as médias nos grupos B e $C$ foram semelhantes. Não existem estudos que correlacionem o número de episódios convulsivos ou o período em que foi realizada a coleta de líquor após as convulsões, com os níveis de proteína C reativa, seja ela liquórica ou sérica. Martínez-Subiela et al. (2011), encontraram níveis baixos de proteína C-reativa no líquor de cães com epilepsia idiopática e outras afecções neurológicas do sistema nervoso central, entretanto, suas amostras foram colhidas de cães com o diagnóstico de epilepsia idiopática sem considerar em que momento havia ocorrido a última crise. No presente estudo, a escolha dos grupos e a especificação do tipo de episódio convulsivo (generalizada tônico-clônica) permitiu melhor avaliação nos cães analisados quanto a possíveis 
elevações das concentrações de proteína $C$ reativa sérica e liquórica. Segundo Thomas (2010), os episódios convulsivos generalizados tônico-clônicos caracterizam-se pelo envolvimento de ambos os hemisférios cerebrais, apresentando estímulos motores bilaterais. Estes estímulos promovem a contração sustentada de todos músculos muitas vezes acompanhada de alterações respiratórias, nas quais a presença de cianose é frequente, acompanhada ou não de sinais autonômicos como salivação, micção e defecação. As alterações observadas nesse tipo de episódio convulsivo são consideradas estímulos importantes para a liberação de citocinas pró-inflamatórias e consequentemente a produção de proteínas de fase aguda (VEZZANI, 2005), o que poderia não ocorrer em outros tipos de convulsões. Assim é possível que, neste estudo, o aumento de $\mathrm{PCR}$ sérica esteja relacionado às contrações musculares dos processos tônicos clônicos.

O exame físico-químico e citológico do líquor não evidenciou alterações nos parâmetros de normalidade nos grupos estudados, mesmo considerando a variação entre a ocorrência de convulsão e o momento de coleta do material. A análise do LCR é considerada importante ferramenta para identificar afecções inflamatórias ou infecciosas no sistema nervoso central. É sabido que as convulsões em humanos são indutoras de pleocitose e do aumento de proteína no exame físico-químico do líquor em afecções encefálicas, porém estas alterações são observadas em apenas $30 \%$ dos casos (EDWARDS et al., 1983; PROKESCH et al., 1983). A avaliação físico-química do líquor em cães realizada por Gonçalves (2010), não identificou alterações nos pacientes estudados, mesmo alguns deles apresentando episódios convulsivos agrupados.

No presente estudo, as amostras foram divididas de acordo com o período em que ocorreram as convulsões, sendo este inferior ou superior a 24 horas, sendo que dentro destes grupos, havia uma variação no numero dos episódios convulsivos entre os cães. Em ambos os grupos B e C, não foram identificadas alterações físicoquímicas, nos níveis de proteína e de celularidade, que são parâmetros importantes para identificação de doenças inflamatórias e infecciosas no sistema nervoso central. Tal fato, demostra que os episódios convulsivos, não foram suficientes para desencadear um processo inflamatório capaz de alterar a composição do LCR, o que não indica que o mesmo não poderia ser identificado por outras técnicas. 
A avaliação de proteína C-reativa liquórica neste estudo foi realizada pelo método ELISA. Segundo Martinez Subiela et al (2011), em estudo comparando o método imunofluorimétrico em tempo resolvido (IFTR) e ELISA, concluíram que o teste IFTR apresentou maior sensibilidade, obtendo valores mínimos detectáveis de $7,1 \times 10^{-6} \mu \mathrm{g} / \mathrm{mL}$, sendo então considerado uma alternativa para a avaliação de proteína C-reativa liquórica em cães com diferentes afecções neurológicas.

Porém, na rotina clínica este teste não é utilizado pela sua complexidade e custo elevado, optando-se ainda pela utilização do método ELISA. Assim, ainda em 2005, Parra et al. analisaram proteína C-reativa sérica no LCR de 35 cães com processos inflamatórios pelas técnicas imunofluorimetrica em tempo resolvido e ELISA e observaram correlação entre os valores obtidos, entretanto, o método imunofluorométrico apresentou maior sensibilidade sendo capaz de detectar valores tão baixos quanto $6,7 \times 10^{-6} \mu \mathrm{g} / \mathrm{mL}$. No presente estudo, na impossibilidade de realização de imunofluorimetria e utilizando-se ELISA observou-se no líquor valores indetectáveis e mínimo detectável de $3,75 \times 10^{-3} \mu \mathrm{g} / \mathrm{mL}$, sendo que a variação entre os valores a partir do citado permitiu análise da proteína C-reativa liquórica entre os grupos estudados. Importante comentar que Parra et al. (2005) e Martinez Subiela et al. (2011), afirmam que o valor mínimo observado e detectável em seus estudos foi de $0,1 \mu \mathrm{g} / \mathrm{mL}$. Este estudo notou valores abaixo deste e este fato pode dever-se à adaptação realizada para poder utilizar o teste ELISA nas amostras de líquor (diluição 1:2).

A metodologia adotada, assim como os valores observados não passaram por processo de validação do teste, o que poderia levar a uma discussão com os valores apresentados na literatura, sendo esta uma limitação do estudo.

O grupo B apresentou concentrações liquóricas médias de 18,66 × $10^{-3}$ $\mu \mathrm{g} / \mathrm{mL}$ (desvio padrão $12,09 \times 10^{-3} \mu \mathrm{g} / \mathrm{mL}$, com valores mínimos não detectáveis e máximos de $43 \times 10^{-3} \mathrm{\mu g} / \mathrm{mL}$ ). Os mesmos dados não foram observados no grupo $\mathrm{C}$ que apresentou valores médios bem inferiores $1,79 \times 10^{-3} \mu \mathrm{g} / \mathrm{mL}$ (mínima não detectável e máxima de $23 \times 10^{-3} \mathrm{\mu g} / \mathrm{mL}$ ). Importante ressaltar que, por mais que as concentrações observadas no grupo $B$ tenham sido elevadas quando comparadas ao grupo $\mathrm{C}$, ainda assim os valores são baixos, já que estudos avaliando as concentrações liquóricas e séricas em diferentes doenças, demostraram valores muito superiores aos encontrados neste estudo. 
Os dados obtidos por Bathen-Noethen e colaboradores em 2008, comparando pacientes apresentando meningite arterite, meningoencefalite, distúrbios do disco intervertebral, tumor do sistema nervoso central e epilepsia idiopática, demonstraram valores bem elevados de proteína C-reativa sérica e liquórica nos cães analisados. No caso de meningite-arterite, foi encontrada média de $142 \mathrm{mg} / \mathrm{mL}$ e $1.59 \mathrm{mg} / \mathrm{mL}$ para PCR sérica e liquórica respectivamente. Essa elevação é significativa quando comparada aos valores deste estudo de $6,36 \mu \mathrm{g} / \mathrm{mL}$ sérico e $18,7 \times 10^{-3} \mu \mathrm{g} / \mathrm{mL}$ liquórico. Quando comparada a avaliação de proteína C-reativa sérica e liquórica realizada por Bathen-Noethen e colaboradores e o presente estudo, nota-se que a mensuração nos cães apresentando epilepsia idiopática, não pode se confundir com os valores obtidos em animais que apresentem afecções inflamatórias e infecciosas como meningite arterite, meningoencefalites, tumores encefálicos entre outras descritas, embora nestas doenças a manifestação do episódio convulsivo também possa estar presente.

As variações, mesmo que em menor magnitude encontradas neste estudo, se bem estabelecidas poderiam servir para diferenciar a epilepsia idiopática de outras doenças inflamatórias uma vez que a redução da PCR foi evidente no período superior a 24 horas das convulsões e nas outras afecções citadas os níveis ainda se manteriam elevados. 


\section{CONCLUSÕES}

Com base nos resultados expostos e na metodologia empregada, concluiu-se que:

a) As convulsões desencadeiam, no animal com epilepsia idiopática, resposta de fase aguda caracterizada pela elevação sérica e liquórica de PCR;

b) O pico da elevação da concentração de PCR ocorre em aproximadamente 24 horas, após o qual ocorre declínio das concentrações, não havendo aumentos detectáveis após 32 horas das convulsões;

c) Não se observou correlação entre o perfil eletroforético, principalmente frações $\beta$ e $\gamma$ (nas quais pode ser encontrada a PCR), com as concentrações séricas de PCR;

d) Não foram encontradas quaisquer alterações nas características físicoquímicas e citológicas do líquor, mesmo em proximidade com o episódio convulsivo;

e) A PCR liquórica determinada pela técnica ELISA acompanhou as variações da PCR sérica, entretanto, o teste precisaria ser validado, o que representa uma limitação do estudo;

f) A PCR pode ser utilizada como um biomarcador para diferenciar epilepsia idiopática de afecções inflamatórias do SNC, já que suas concentrações sericas/liquóricas nos casos de epilepsia idiopática decrescem após a ocorrência da convulsão. 


\section{REFERÊNCIAS}

ABERNETHY,T. J.; AVERY, O. T. The occurence during acute infections of a protein not normally present in the blood. I. Distribution of the reactive protein in patients' sera and the effect of calcium on the flocculation reaction with C-polysaccharide of pneumococcus. Journal of Experimental Medicine. v. 73, p. 173-182, 1940.

AMINOFF, M. J.; SIMON, R. P. Status epilepticus. Causes, clinical features and consequences in 98 patients. American Journal of Medicine, v. 69, 657-666, 1980.

ANDERSON, H. C.; MCCARTY, M. Determination of C-reactive protein in the blood as a measure of the activity of the disease process in acute rheumatic fever.

American Journal of Medicine, v. 8, p. 445-455, 1950.

BATHEN-NOETHEN, A.; CARLSON, R.; MENZEL, D.; MISCHKE, R.; TIPOLD, A. Concentrations of Acute-Phase Proteins in Dogs with Steroid Responsive MeningitisArteritis, Journal of Veterinary Internal Medicine, v. 22, n. 5, p. 1149-1156, 2008.

BERENDT, M.; GRAM, L. Epilepsy and seizure classification in 63 dogs: a reappraisal of veterinary epilepsy terminology. Journal of veterinary internal medicine, v. 13, p. 14, 1999.

BILATE, A. M. B. Inflamação, citocinas, proteínas de fase aguda e implicações Terapêuticas. Temas de reumatologia clínica, v. 8, n. 2, 2007.

BRAUND, K. G. Clinical syndromes in veterinary neurology, 2. ed. St. Louis Mosby, 1994. p. 477.

BURTON, S. A.; HONOR, D. J.; MACKENZIE, A. L.; ECKERSALL, P. D.; MARKHAM, R. J. F.; HORNEY, B. S. C-reactive protein concentration in dogs with inflammatory leukograms. American Journal of Veterinary Research, v. 55, p. 613618, 1994.

CARBONNELLE, E. Laboratory diagnosis of bacterial meningitis: usefulness of various tests for the determination of the etiological agent. Médecine et maladies infectieuses, v. 39, p. 581-605, 2009. 
CASAL, M. L.; MUNUVE, R. M.; JANIS, M. A.; WERNER, P.; HENTHORN, P. S. Epilepsy in Irish Wolfhounds. Journal of veterinary internal medicine, v. 20, p. 131-135, 2006.

CASPI, D.; BALTZ, M. L.; SNEL, F.; GRUYS, E.; NIV, D.; BATT, R. M.; MUNN, E. A. Isolation and characterization of $C$-reactive protein from the dog. Immunology, $v$. 53, p. 307-313, 1984.

CERÓN, J. J.; ECKERSALL, P. D.; MARTINEZ-SUBIELA, S. Acute phase proteins in dogs and cats: current knowledge and future perspectives. Veterinary Clinical Pathology, Santa Barbara, v. 34, p. 85-99, 2005.

CHANDLER, K. Canine epilepsy. What can we learn from human seizure disorders ? The Veterinary Journal, v. 172, n. 2, p. 207-217, 2006.

CHANDLER, K.; VOLK, H. Seizures: Intracranial or extracranial disease? In Pract , v. 30, p. $366-373,2008$.

CONNER, J. G.; ECKERSALL, P. D.; FERGUSON, J.; DOUGLAS, T. A. Acute phase response in the dog following surgical trauma. Research in Veterinary Science, v. 45, p. 107-110, 1988.

DE LAHUNTA, A.; GLASS, E. N. Seizures-Convulsions. In De Lahunta A, Veterinary Neuroanatomy and Clinical Neurology. 3 ed. WB Saunders, 2008. p. 457-468.

DEWEY, C. W.; THOMAS, W. B. Seizures and Narcolepsy. In Dewey CW. A Practical Guide to Canine and Feline Neurology. 2 ed, 2008. v. 7, p. 237-253.

DILLMAN, R. C.; COLES, E. H. A canine serum fraction analogous to human Creactive protein. American Journal of Veterinary Research, v. 27, p. 1769-1775, 1966.

DINARELLO, C. A. Interleukin-1. Cytokine \& Growth Factor Reviews, v. 8, p. 253265, 1997.

DI TERLIZZI, R.; PLATT, S. R. The function, composition and analysis of cerebrospinal fluid in companion animals: Part I - Function and composition, The Veterinary Journal, v. 172, n. 3, p. 422-431, 2006. 
DI TERLIZZI, R.; PLATT, S. R. The function, composition and analysis of cerebrospinal fluid in companion animals: Part II - Analysis, The Veterinary Journal, v. 180, n. 1, p. 15-32, 2009.

ECKERSALL, P. D.; CONNER, J. G.; PARTON, H.; NASH, A. S.; WATSON, T.; DOUGLAS, A. T.; BLACKMORE, D. J. Acute phase reactants in diseases of dog and cattle. Animal clinical biochemistry of the future, p. 225-230, 1988.

ECKERSALL, P. D.; CONNER, J. G.; HARVIE, J. An immunoturbidimetric assay for canine C-reative protein. Veterinary Research Communications, v. 15, n. 1, p. 1724, 1991.

ECKERSALL, P. D.; BELL, R. Acute phase proteins: Biomarkers of infection and inflammation in veterinary medicine. The Veterinary Journal. , v. 185(1), p. 23-27, 2010.

EDWARDS, R.; SCHMIDLEY, J. W.; SIMON, R. P. How often does a CSF pleocytosis follow generalized convulsions? Annals of Neurology, v. 13, 460-462, 1983.

ENGEL, J. Report of the ILAE classification core group. Epilepsia Journal, v. 47, p. 1558-1568, 2006.

FARNBACK, G.C. Seizures in dogs. Part I. Basis, classification and prediction.

Compendium on Continuing Education. Small Animal Practice, v. 6, n. 6, p. 569574, 1984.

GANROT, K. Plasma protein response in experimental inflammation in the dog. Research Experimental Medicine, v.161, p. 251-26, 1973.

GONÇALVES, R.; ANDERSON, T. J.; INNOCENT, G.; PENDERIS, J. Effect of seizures on cerebrospinal fluid analysis in dogs with idiopathic epilepsy. Veterinary Record, v.166, p. 497-498, 2010.

GOTSCHLICH, E.C. Occurence of a substance analogous to C-reactive protein in acute phase dog sera. Federation Proceedings, v. 21, p. 14, 1962. 
GORTER, J. A.; VAN VLIET, E. A.; ARONICA, E.; BREIT, T.; RAUWERDA, H.; LOPES DA SILVA, F.H.; WADMAN, W.J. Potential new antiepileptogenic targets indicated by microarray analysis in a rat model for temporal lobe epilepsy. Journal Neuroscience, v. 26, p. 11083-11110, 2006.

GRUENENFELDER, F. Seizures and Sleep Disorders, In Morgan RV. (ed): Handbook of Small Animal Practice. 5 ed. 2008. v. 22, p. 222-230.

GRUYS, E.; OBWOLO, M. J.; TOUSSAINT, M. J. M. Diagnostic significance of the major acute phase proteins in veterinary clinical chemistry: a review. Veterinary Bulletin , v. 64, p. 1009-1018, 1994.

GRUYS, E.; TOUSSAINT, M. J. M.; NEIWOLD T. A.; KOOPMANS S. J. Acute phase reaction and acute phase proteins. Journal Zhejiang University Science, v. 6, p. 1045-1056, 2005.

HEINRICH P. C.; CASTELL J. V.; ANDUS T. Interleukin- 6 and the acute phase response. The Biochemical journal, v. 265, p. 621-636, 1990.

HÜLSMEYER, V.; ZIMMERMANN, R.; BRAUER, C.; SAUTER-LOUIS, C.; FISCHER, A. Epilepsy in Border Collies: Clinical Manifestation, Outcome, and Mode of Inheritance. Journal of veterinary internal medicine, v. 24, p. 171-178, 2010.

JAGGY, A.; BERNARDINI, M. Idiopathic epilepsy in 125 dogs: a long-term study. Clinical and electroencephalographic findings. The Journal of small animal practice, v. 38, p. 23-29, 1998.

JAIN, N. C. Acute phase proteins. In: KIRK, R.W. Current veterinary therapy X : small animal practice. Philadelphia: Saunders, 1989. p.468-471.

JAIN, S.; GAUTAM, V.; NASEEM, S. Acute-phase proteins: As diagnostic tool. Journal Pharma Bioallied Science, v. 3 , n. 1, p. 118-127, 2011.

JANKOWSKY, J. L.; PATTERSON, P. H. The role of cytokines and growth factors in seizures and their sequelae. Progress in neurobiology, v. 63, p. 125-149, 2001.

KANEKO, J. J. Serum proteins and the dysproteinemias. In : KANEKO, J. J.; HARVEY, J. W.; BRUSS, M. L. Clinical biochemistry of domestic animals. 7. ed. San Diego: Academic Press, 1989. p. 912. 
KOJ, A. Cytokines regulating acute inflammation and synthesis of acute phase proteins. Perspektiven in Medizin, v. 51, p. 267-274, 1985.

KUSHNER,I.; GANAPATHI, M.; SCHULTZ, D. The acute phase response is mediated by heterogeneous mechanisms. Annals of the New York Academy of Science, v. 557, p. 19-29, 1989.

LECOUTEUR, R. A.; VERNAU, K. M. Seizures and Status Epilepticus, In: SILVERSTEIN, D. C.; D.V.M. HOPPER, K. ( Ed.). Small Animal Critical Care Medicine, Saint Louis : W.B. Saunders, 2009. chp. 98, p. 414-419.

MACLEOD, C.M.; AVERY, O. T. The occurence during acute infections of a protein not normally present in the blood. III. Immunological properties of the C-reactive protein and its differentation from normal blood proteins. Journal of Experimental Medicine, v. 73, p. 191-200, 1941.

MARTíNEZ-SUBIELA, S.; TECLES, F.; PARRA, M. D.; CERÓN, J. J. Proteínas de fase aguda: conceptos básicos y principales aplicaciones clínicas en medicina veterinária. Annals Veterinary (MURCIA), v. 17, p. 97-114, 2001.

MARTINEZ-SUBIELA, S.; CALDIN, M.; Parra, M. D.; OTTOLINI, BERTOLINI, N. J.; BERNAL, L. J.; GARCIA-MARTINEZ, J. D.; Ceron, J. J. Canine C-reactive protein measurements in cerebrospinal fluid by a time-resolved immunofluorimetric assay, $\mathrm{J}$ Journal of veterinary diagnostic investigation, v. 23, p. 63-67, 2011.

MCCARTY, M. The occurence during acute infections of a protein not normally present in the blood. IV. Crystalization of the C-reactive protein. Journal of Experimental Medicine, v. 85, p. 491-498, 1947.

MCGROTTY, Y. L.; KNOTTENBELT, C. M.; RAMSEY, I. K.; REID, S. W. J.; ECKERSALL, P. D. Evaluation of a rapid assay for canine C-reative protein. Veterinary Record, v. 154, n. 6, p. 175-176, 2004.

MORITA, T.; TAKAHASHI, M.; TAKEUCHI, T.; HIKASA, Y.; IKEDA, S.; SAWADA, M.; SATO, K.; SHIBAHARA, T.; SHIMADA, A. Changes in ex-tracellular neurotransmitters in the cerebrum of familial idiopathic epileptic shetland sheepdogs using an intracerebral microdi-alysis technique and immunohistochemical study for glutamate metabolism. The Journal of veterinary medical science, v. 67, p. 11191126, 2005. 
MURATA, H.; SHIMADA, N.; YOSHIOKA, M. Current research on acute phase proteins. Veterinary diagnosis: an overview. The Veterinary Journal, v. 168, p. 2840, 2004.

PARENT, J. The Diagnostic and Therapeutic Approach to Recurrent Seizures in the Dog. In WSAVA, 29 ${ }^{\text {th }}$., 2004, Greece. 2004. P.57-60.

PARRA, M. D.; TUOMOLA, M.; CABEZAS-HERRERA, J.; CERON, J. J. Use of a time-resolved immunofluorometric assay for determination of canine $C$-reativa protein concentrations in whole blood. American Journal of Veterinary Research, v. 66, n. 1, p. 62-66, 2005.

PELTOLA, J.; LAAKSONEN, J.; HAAPALM, A. M.; HURME, M.; RAINESALO, S.; KERANEN, T. Indicators of inflammation after recent tonic-clonic epileptic seizures correlate with plasma interleukin-6 levels, Seizure, v. 11, p. 44-46, 2002.

PEPYS, M. B.; BALTZ, M.L. Acute phase proteins with special reference to Creactive protein and related proteins (pentraxins) and serum amyloid $A$ protein. In: Advances in immunology, DIXON, W. J.; KUNKEL, H. G. New York: Academic Press, 1983. p. 141-212.

PETERSEN, H. H.; NIELSEN, J. P.; HEEGAARD, P. M. H. Application of acute phase protein measurement in veterinary clinical chemistry. Veterinary Research, v. 35, p. 163-187, 2004.

PLATT, S. R.; MCDONNELL, J. J. Status epilepticus: Clinical features and pathophysiology. Compendium Continued Education Practice Veterinary, v. 22, p. 660-669, 2000.

PLATT, S. R.; HAAG, M. Canine status epilepticus: a retrospective study of 50 cases. Journal Small Animal Practice, v. 43, p. 151-153, 2002.

PODELL, M.; FENNER, W. R.; POWERS, J. D. Seizure classification in dogs from a nonreferral based population. Journal American Veterinary Medical Association, v. 206, p. 1721-1728, 1995.

PODELL, M. Seizures. In: PLATT, R. S.; OLBY, N. (Ed.). BSAVA Manual of Canine and Feline Neurology. 3 ed. BSAVA, 2004. v. 7, p. 97-112. 
PODELL, M. Epilepsy 101: guiding principles for diagnosis and treatment.

Proceeding of American College of Veterinary Internal Medicine, Northbrook, 2006.

PODELL M. Seizures. In: ETTINGER, S. J., FELDMAN, E. C. Textbook of Veterinary Internal Medicine. 7. ed. Missouri: Elsivier Saunders, 2010. v. 57, p. 228-230.

PROKESCH, R. C.; RIMLAND, D.; PETRINI, J. L.; FEIN, A. B. Cerebrospinal fluid pleocytosis after seizures. Southern Medical Journal 76, 322-327, 1983.

QUESNEL, A. D. Seizures. In ETTINGER, S. J., FELDMAN, E. C., Ed. Textbook of veterinary internal medicine: diseases of the dog and cat. 6. ed. Missouri: Elsivier Saunders, 2005. p. 164-170.

REYNOLD, E.H. Epilepsy global campaign history. Epilepsia , v. 43, p. 9-11, 2002.

RILEY, R. F.; COLEMAN, M. K. Isolation of C-reactive proteins of man monkey, rabbit and dog by affinity chromatography on phosphorylated cellulose. Clinic Chimica Acta, v. 30, p. 483-496, 1970.

RILEY, R. F.; ZONTINE, W. Further observations on the properties of dog C-reactive protein and the C-reactive protein response in the dog. Journal of Laboratory and Clinical Medicine, v. 80, p. 698-703, 1972

SCHMIDLEY, J. W.; SIMON, R. P. Postictal pleocytosis, Annals of Neurology, v. 9, p. 81-84, 1981.

SCHRIEFL, S.; STEINBERG, T. A.; MATIASEK, K. Etiologic classification of seizures, signalment, clinical signs, and outcome in cats with seizure disorders: 91 cases (2000-2004). Journal American Veterinary Medical Association, v. 233, p. 1591-1597, 2008.

SMITH, S. EEG in the diagnosis, classification, and management of patients with epilepsy. J Neurology Neurosurg Psychiatry, v. 76, p. 112-17, 2005. 
TAGATA, K.; YOKOYAMA, S.; GINBO, T.; HONDA, M.; OKIMURA, T.; ODAKURA, M.; NOMURA, M.; YAMAMOTO, S. Quantitative capillary reversed passive látex agglutination test for $\mathrm{C}$-reactive protein (CRP) in the dog. Veterinary Research Communications, v. 20, n. 1, p. 21-30, 1996.

TANKHIWALE, S. S.; JAGTAP, P. M.; KHADSE, R. K.; JALGAONKAR, S. V. Bacteriological study of pyogenic meningitis with special reference to $C$-reactive protein. Indian Journal Medical Microbiology, v. 19, p. 159-160, 2001.

TAYLOR, A. W.; MORTENSEN, R. F. Both human IL-1 and IL-6 induce synthesis of C-reactive protein (CRP) by the PLC/PRF/5 hepatoma cell line. Annals of the New York Academy of Science, v. 557, p. 532-533, 1989.

TILLET,W. S.; FRANCIS, T. Serological reactions in pneumonia with a non protein somatic fraction of pneumococcus. Journal of Experimental Medicine, v. 52, p. 561-571, 1930.

THOMAS, W. B. Idiopathic epilepsy in dogs. Small Animal Practive, v. 30, p. 183206, 2000.

THOMAS, W. B. Idiopathic epilepsy in dogs and cats. Veterinary Clinic Small Animal., n. 40, p. 161-179, 2010.

TORRES, H. M. Eletroforese de proteínas. Richet Nouvelles, Rio de Janeiro, v. 3, p. $1-4,2008$

TURRIN, N. P.; RIVEST, S. Innate immune reaction in response to seizures: implications for the neuropathology associated with epilepsy. Neurobiology, v. 16, . p. 321-324, 2004.

TVEDTEN, H. W. Clinical pathology of bovine neurologic disease. Veterinary Clinics of North America: Food Animal Practice, v. 3, n. 1, p. 25-44, 1987.

VAN ZYL, L. C. Eletrophoresis of ovine plasma proteins of cellulose acetate: the technique as adapted to standard equipment for use with filter papers strips. Journal of South African Veterinary Medical Association, v. 37, n. 4, p. 460-464, 1966. 
VEZZANI, A.; GRANATA, T. Brain inflammation in epilepsy: experimental and clinical evidence. Epilepsia, v. 46, p. 1724-1743, 2005.

WAMSLEY, H.; ALLEMAN, A. R. Clinical pathology. In PLATT, R. S, OLBY, N. (Ed) BSAVA manual of canine and feline neurology. 3. ed. BSAVA, 2004. , v. 3, p. 35-53.

YAMAMOTO, S.; TAGATA, K.; NAGAHATA, H.; ISHIKAWA, Y.; MORIMATSU, M.; NAIKI, M. Isolation of canine C-reactive protein and characterization of its properties. Veterinary Immunology and Immunopathology, v. 30, p. 329-339, 1992.

YAMAMOTO, S.; SHIDA, T.; MIYAJI, S.; SANTSUKA, H.; FUJISE, H.; MUKAWA, K.; FURUKAWA, E.; SARIKAPUTI, M.; NAIKI, M. Determination of C-reactive protein levels in dogs with various disorders and surgical traumas. Veterinary Research Communications, v. 17, n. 2, p. 85-93, 1993.

YAMAMOTO, S., SHIDA, T., HONDA, M., ASHIDA, Y., RIKIHISA, Y., ODAKURA, M., HAYASHI, S., NOMURA, M., ISAYAMA, Y. Serum C-reactive protein and immune responses in dogs inoculated with Bordetella bronchiseptica (phase I cells).

Veterinary Research Communications, v. 18, p. 347-357, 1994.

ZIMMERMANN, R.; HÜLSMEYER V. I.; SAUTER-LOUIS, C.; FISCHER, A. Status Epilepticus and Epileptic Seizures in Dogs. Journal Veterinary Internal Medicine, v. 23, p. 970-976, 2009. 


\section{APÊNDICES}

Apêndice A: Tabela representando hemograma dos animais pertencentes ao grupo $\mathrm{A}$ controle. Hemácias ( $\mathrm{He}$ milhões $/ \mathrm{mm}^{3}$ ), Hematócrito ( $\left.\mathrm{Ht} / \%\right)$, Hemoglobina ( $\mathrm{Hb} / \mathrm{g} / \mathrm{dL}$ ), Volume corpuscular médio (VCM / fl), Hemoglobina corpuscular média ( $\mathrm{HCM} / \mathrm{pg}$ ), Concentração de hemoglobina corpuscular média (CHCM / \%), Leucócitos (Leuc / $\mathrm{mm}^{3}$ ), Neutrófilos $\left(\mathrm{Neu} / \mathrm{mm}^{3}\right)$, Eosinófilos (Eos $\left./ \mathrm{mm}^{3}\right)$, Basófilos (Bas $/ \mathrm{mm}^{3}$ ), Linfócitos Típicos (Linf $\left./ \mathrm{mm}^{3}\right)$, Monócitos $\left(\mathrm{Mon} / \mathrm{mm}^{3}\right)$, Plaquetas (Plaq $\times 10^{3}$ ) - São Paulo - 2012

\begin{tabular}{|c|c|c|c|c|c|c|c|c|c|c|c|c|c|}
\hline Animal & $\mathrm{He}$ & $\mathrm{Ht}$ & $\mathrm{Hb}$ & VCM & HCM & СНCM & Leuc & Neu & Eos & Bas & Linf & Mon & Plaq \\
\hline A1 & 7,2 & 46 & 16,1 & 63 & 22 & 35 & 8800 & 4664 & 792 & 0 & 2728 & 616 & 269 \\
\hline A2 & 6,1 & 40 & 13,3 & 67 & 22 & 33 & 11100 & 5772 & 1332 & 111 & 3552 & 333 & 320 \\
\hline A3 & 7,7 & 51 & 16,9 & 66 & 22 & 33 & 7700 & 5544 & 308 & 0 & 1540 & 308 & 210 \\
\hline A4 & 7,7 & 51 & 16,6 & 66 & 21 & 32 & 9500 & 6650 & 190 & 0 & 1615 & 1045 & 414 \\
\hline A5 & 7,0 & 44 & 14,4 & 62 & 20 & 33 & 9200 & 6808 & 736 & 0 & 1012 & 644 & 396 \\
\hline A6 & 8,1 & 50 & 16,1 & 62 & 20 & 32 & 9600 & 6144 & 864 & 0 & 2112 & 480 & 339 \\
\hline A7 & 8,0 & 56 & 18,8 & 70 & 23 & 33 & 7700 & 5467 & 77 & 0 & 1771 & 385 & 403 \\
\hline A8 & 8,8 & 49 & 16,2 & 56 & 18 & 33 & 6900 & 4209 & 897 & 0 & 1104 & 690 & 258 \\
\hline A9 & 7,2 & 50 & 16 & 70 & 22 & 32 & 12400 & 8432 & 1612 & 0 & 1736 & 620 & 280 \\
\hline A10 & 7,8 & 51 & 16,3 & 65 & 21 & 32 & 6300 & 4599 & 126 & 0 & 1197 & 378 & 210 \\
\hline A11 & 8,6 & 58 & 18,8 & 67 & 22 & 32 & 9600 & 6048 & 1152 & 96 & 1824 & 480 & 264 \\
\hline A12 & 7,8 & 51 & 16,9 & 65 & 21 & 33 & 8900 & 4984 & 1068 & 0 & 2492 & 356 & 263 \\
\hline A13 & 6,0 & 40 & 12,8 & 66 & 21 & 32 & 10.600 & 8692 & 106 & 0 & 1590 & 212 & 412 \\
\hline A14 & 8,5 & 55 & 18,6 & 65 & 22 & 33 & 8000 & 6240 & 80 & 0 & 1360 & 320 & 447 \\
\hline A15 & 8,9 & 62 & 20,7 & 70 & 23 & 33 & 8100 & 4050 & 810 & 0 & 2430 & 810 & 222 \\
\hline A16 & 7,8 & 54 & 18,2 & 69 & 23 & 34 & 11300 & 5424 & 1582 & 0 & 3842 & 452 & 302 \\
\hline A17 & 8,2 & 56 & 19,2 & 69 & 23 & 34 & 9300 & 5766 & 930 & 0 & 2139 & 465 & 270 \\
\hline A18 & 7,2 & 51 & 17,6 & 70 & 24 & 35 & 15600 & 10296 & 780 & 0 & 3900 & 624 & 318 \\
\hline A19 & 7,3 & 49 & 16,3 & 68 & 22 & 33 & 13600 & 10608 & 1088 & 0 & 1768 & 136 & 348 \\
\hline A20 & 7,4 & 51 & 16,8 & 69 & 22 & 33 & 6700 & 3953 & 603 & 0 & 1876 & 268 & 238 \\
\hline A21 & 7,8 & 55 & 19,4 & 70 & 25 & 35 & 6800 & 4624 & 680 & 0 & 1292 & 204 & 346 \\
\hline A22 & 7,8 & 51 & 17,7 & 66 & 23 & 35 & 6200 & 3720 & 496 & 0 & 1736 & 248 & 275 \\
\hline A23 & 8,3 & 58 & 19,6 & 70 & 24 & 34 & 11600 & 5800 & 464 & 0 & 4872 & 464 & 307 \\
\hline
\end{tabular}


Apêndice B: Tabela representando hemograma dos animais pertencentes ao grupo B. Hemácias ( He milhões $/ \mathrm{mm}^{3}$ ), Hematócrito $(\mathrm{Ht} / \%)$, Hemoglobina $(\mathrm{Hb} / \mathrm{g} / \mathrm{dL})$, Volume corpuscular médio (VCM / fl), Hemoglobina corpuscular média (HCM / pg), Concentração de hemoglobina corpuscular média (CHCM / \%), Leucócitos (Leuc / $\mathrm{mm}^{3}$ ), Neutrófilos (Neu / $\left.\mathrm{mm}^{3}\right)$, Eosinófilos (Eos $\left./ \mathrm{mm}^{3}\right)$, Basófilos (Bas $/ \mathrm{mm}^{3}$ ), Linfócitos Típicos (Linf $\left./ \mathrm{mm}^{3}\right)$, Monócitos $\left(\mathrm{Mon} / \mathrm{mm}^{3}\right)$, Plaquetas (Plaq $\times 10^{3}$ ) - São Paulo - 2012

\begin{tabular}{|ccccccccccccccc}
\hline Animal & He & Ht & Hb & VCM & HCM & CHCM & Leuc & Neu & Eos & Bas & Linf & Mon & Plaq \\
\hline B1 & 7,8 & 54 & 18,2 & 69 & 23 & 34 & 11300 & 5424 & 1582 & 0 & 3842 & 452 & 302 \\
\hline B2 & 6,8 & 27 & 11,2 & 67 & 22 & 33 & 11100 & 5772 & 1332 & 111 & 3552 & 333 & 320 \\
\hline B3 & 7,2 & 51 & 16,9 & 66 & 22 & 33 & 7700 & 5544 & 308 & 0 & 1540 & 308 & 210 \\
\hline B4 & 7,8 & 51 & 16,6 & 66 & 21 & 32 & 9500 & 6650 & 190 & 0 & 1615 & 1045 & 414 \\
\hline B5 & 7,2 & 44 & 14,4 & 62 & 20 & 33 & 9200 & 6808 & 736 & 0 & 1012 & 644 & 396 \\
\hline B6 & 7,8 & 50 & 16,1 & 62 & 20 & 32 & 9600 & 6144 & 864 & 0 & 2112 & 480 & 339 \\
\hline B7 & 7,0 & 56 & 18,8 & 70 & 23 & 33 & 7700 & 5467 & 77 & 0 & 1771 & 385 & 403 \\
\hline B8 & 8,1 & 49 & 16,2 & 56 & 18 & 33 & 6900 & 4209 & 897 & 0 & 1104 & 690 & 258 \\
\hline B9 & 7,9 & 50 & 16.0 & 70 & 22 & 32 & 12400 & 8432 & 1612 & 0 & 1736 & 620 & 280 \\
\hline B10 & 6,0 & 51 & 16,3 & 65 & 21 & 32 & 6300 & 4599 & 126 & 0 & 1197 & 378 & 210 \\
\hline B11 & 6,8 & 58 & 18,8 & 67 & 22 & 32 & 9600 & 6048 & 1152 & 96 & 1824 & 480 & 264 \\
\hline B12 & 6,5 & 51 & 16,9 & 65 & 21 & 33 & 8900 & 4984 & 1068 & 0 & 2492 & 356 & 263 \\
\hline B13 & 6,0 & 40 & 12,8 & 66 & 21 & 32 & 10.600 & 8692 & 106 & 0 & 1590 & 212 & 412 \\
\hline B14 & 8,5 & 55 & 18,6 & 65 & 22 & 33 & 8000 & 6240 & 80 & 0 & 1360 & 320 & 447 \\
\hline B15 & 8,9 & 62 & 20,7 & 70 & 23 & 33 & 8100 & 4050 & 810 & 0 & 2430 & 810 & 222 \\
\hline B16 & 7,8 & 54 & 18,2 & 69 & 23 & 34 & 11300 & 5424 & 1582 & 0 & 3842 & 452 & 302 \\
\hline B17 & 8,2 & 56 & 19,2 & 69 & 23 & 34 & 9300 & 5766 & 930 & 0 & 2139 & 465 & 270 \\
\hline
\end{tabular}


Apêndice C: Tabela representando hemograma dos animais pertencentes ao grupo C. Hemácias ( He milhões $/ \mathrm{mm}^{3}$ ), Hematócrito $(\mathrm{Ht} / \%)$, Hemoglobina $(\mathrm{Hb} / \mathrm{g} / \mathrm{dL})$, Volume corpuscular médio (VCM / fl), Hemoglobina corpuscular média ( $\mathrm{HCM} \mathrm{/} \mathrm{pg),}$ Concentração de hemoglobina corpuscular média (CHCM / \%), Leucócitos (Leuc / $\mathrm{mm}^{3}$ ), Neutrófilos (Neu / $\left.\mathrm{mm}^{3}\right)$, Eosinófilos (Eos $/ \mathrm{mm}^{3}$ ), Basófilos (Bas $/ \mathrm{mm}^{3}$ ), Linfócitos Típicos (Linf $\left./ \mathrm{mm}^{3}\right)$, Monócitos $\left(\mathrm{Mon} / \mathrm{mm}^{3}\right)$, Plaquetas (Plaq $\times 10^{3}$ ) - São Paulo - 2012

\begin{tabular}{|ccccccccccccccc}
\hline Animal & He & Ht & Hb & VCM & HCM & CHCM & Leuc & Neu & Eos & Bas & Linf & Mon & Plaq \\
\hline C1 & 7,7 & 51 & 17,0 & 66 & 22 & 33 & 9036 & 5.432 & 732 & 0 & 2756 & 0 & 116 \\
\hline C2 & 7,4 & 47 & 14,8 & 63 & 20 & 32 & 7083 & 4.389 & 226 & 0 & 2153 & 0 & 315 \\
\hline C3 & 7,2 & 52 & 16,8 & 72,22 & 23 & 32 & 12900 & 8.514 & 516 & 0 & 3483 & 0 & 387 \\
\hline C4 & 7,7 & 51 & 17,0 & 66 & 22 & 33 & 9036 & 5.432 & 732 & 0 & 2756 & 0 & 116 \\
\hline C5 & 7,2 & 44 & 14,4 & 62 & 20 & 33 & 9200 & 6808 & 736 & 0 & 1012 & 644 & 396 \\
\hline C6 & 7,8 & 50 & 16,1 & 62 & 20 & 32 & 9600 & 6144 & 864 & 0 & 2112 & 480 & 339 \\
\hline C7 & 7,0 & 56 & 18,8 & 70 & 23 & 33 & 7700 & 5467 & 77 & 0 & 1771 & 385 & 403 \\
\hline C8 & 8,1 & 49 & 16,2 & 56 & 18 & 33 & 6900 & 4209 & 897 & 0 & 1104 & 690 & 258 \\
\hline C9 & 7,9 & 50 & 16,0 & 70 & 22 & 32 & 12400 & 8432 & 1612 & 0 & 1736 & 620 & 280 \\
\hline C10 & 6,0 & 51 & 16,3 & 65 & 21 & 32 & 6300 & 4599 & 126 & 0 & 1197 & 378 & 210 \\
\hline C11 & 7,9 & 52 & 16,2 & 65 & 21 & 32 & 7200 & 4.968 & 144 & 0 & 1.728 & 0 & 360 \\
\hline C12 & 6,5 & 51 & 16,9 & 65 & 21 & 33 & 8900 & 4984 & 1068 & 0 & 2492 & 356 & 263 \\
\hline C13 & 8,9 & 62 & 20,7 & 70 & 23 & 33 & 8100 & 4050 & 810 & 0 & 2430 & 810 & 222 \\
\hline C14 & 7,8 & 54 & 18,2 & 69 & 23 & 34 & 11300 & 5424 & 1582 & 0 & 3842 & 452 & 302 \\
\hline C15 & 6,0 & 40 & 12,8 & 66 & 21 & 32 & 10600 & 8692 & 106 & 0 & 1590 & 212 & 412 \\
\hline C16 & 8,5 & 55 & 18,6 & 65 & 22 & 33 & 8000 & 6240 & 80 & 0 & 1360 & 320 & 447 \\
\hline
\end{tabular}


Apêndice D: Tabela representando parâmetros bioquímicos dos animais pertencentes ao grupo A controle - São Paulo - 2012

\begin{tabular}{|c|c|c|c|c|c|c|}
\hline Animal & $\begin{array}{l}\text { Uréia } \\
\text { (mg/dL) }\end{array}$ & $\begin{array}{l}\text { Creatinina } \\
\text { (mg/dL) }\end{array}$ & $\begin{array}{c}\text { Proteína } \\
\text { Total } \\
\text { (g/dL) }\end{array}$ & $\begin{array}{c}\text { Albumina } \\
\text { (g/dL) }\end{array}$ & $\begin{array}{l}\text { ALT } \\
\text { (U/L) }\end{array}$ & $\begin{array}{c}\text { Fosfatase } \\
\text { Alcalina } \\
\text { (U/L) }\end{array}$ \\
\hline $\mathrm{A} 1$ & 49,9 & 0,9 & 5,1 & 2,6 & 25,4 & 32 \\
\hline A2 & 19,9 & 1,1 & 6,5 & 3,1 & 24,1 & 84 \\
\hline $\mathrm{A} 3$ & 30,4 & 0,9 & 6,2 & 3,4 & 26,7 & 27 \\
\hline A4 & 34,8 & 0,9 & 7,1 & 3,4 & 48,8 & 29 \\
\hline A5 & 24,7 & 0,8 & 6,1 & 3,1 & 19,6 & 80 \\
\hline A6 & 23,6 & 0,9 & 6,6 & 3,2 & 19,5 & 50 \\
\hline A7 & 30,7 & 1,1 & 6,0 & 3,3 & 14,2 & 23 \\
\hline A8 & 33,6 & 1,0 & 5,8 & 3,1 & 20,4 & 21 \\
\hline A9 & 25,4 & 1,0 & 6,8 & 3,3 & 30,5 & 54 \\
\hline A10 & 33,9 & 0,6 & 6,6 & 3,5 & 30,9 & 24 \\
\hline A11 & 31,5 & 1,2 & 7,2 & 3,2 & 14,4 & 34 \\
\hline $\mathrm{A} 12$ & 25,4 & 1,5 & 6,6 & 3,1 & 11,4 & 17 \\
\hline A13 & 33,9 & 0,8 & 6,2 & 3,1 & 19,5 & 55 \\
\hline A14 & 31,5 & 1,3 & 6,8 & 3,9 & 13,4 & 19 \\
\hline A15 & 25,7 & 0,8 & 6,2 & 3,5 & 17,8 & 23 \\
\hline A16 & 33,0 & 1,0 & 6,8 & 3,4 & 9,4 & 19 \\
\hline A17 & 57,9 & 0,97 & 6,6 & 3,3 & 8,0 & 8 \\
\hline A18 & 24,7 & 1,0 & 6,4 & 3,0 & 7,8 & 15 \\
\hline A19 & 38,4 & 0,87 & 6,7 & 3,5 & 15,4 & 15 \\
\hline A20 & 27,4 & 1,0 & 5,8 & 3,5 & 26,1 & 44 \\
\hline A21 & 37,6 & 1,0 & 7,1 & 3,5 & 37,4 & 16 \\
\hline A22 & 23,4 & 1,0 & 6,3 & 3,8 & 18,1 & 34 \\
\hline A23 & 45,8 & 1,0 & 6,0 & 3,1 & 14,0 & 49 \\
\hline
\end{tabular}


Apêndice E: Tabela representando parâmetros bioquímicos dos animais pertencentes ao grupo B - São Paulo - 2012

\begin{tabular}{ccccccc} 
Animal & $\begin{array}{c}\text { Uréia } \\
(\mathrm{mg} / \mathrm{dL})\end{array}$ & $\begin{array}{c}\text { Creatinina } \\
(\mathrm{mg} / \mathrm{dL})\end{array}$ & $\begin{array}{c}\text { Proteína } \\
\text { Total } \\
(\mathrm{g} / \mathrm{dL})\end{array}$ & $\begin{array}{c}\text { Albumina } \\
(\mathrm{g} / \mathrm{dL})\end{array}$ & $\begin{array}{c}\text { ALT } \\
(\mathrm{U} / \mathrm{L})\end{array}$ & $\begin{array}{c}\text { Fosfatase } \\
\text { Alcalina } \\
(\mathrm{U} / \mathrm{L})\end{array}$ \\
\hline B1 & 42,0 & 0,9 & 5,1 & 2,6 & 42,0 & 112 \\
\hline B2 & 25,4 & 1,0 & 6,5 & 3,1 & 41,2 & 100 \\
\hline B3 & 30,0 & 1,0 & 6,2 & 3,4 & 62,7 & 78 \\
\hline B4 & 33,4 & 1,0 & 7,1 & 3,4 & 79,0 & 92 \\
\hline B5 & 27,2 & 0,9 & 6,1 & 3,1 & 92,0 & 132 \\
\hline B6 & 26,3 & 0,9 & 6,6 & 3,2 & 73,4 & 87 \\
\hline B7 & 37,4 & 1,0 & 6 & 3,3 & 67,2 & 130 \\
\hline B8 & 36,3 & 1,1 & 5,8 & 3,1 & 40,0 & 98 \\
\hline B9 & 24,1 & 1,0 & 6,8 & 3,3 & 66,5 & 79 \\
\hline B10 & 39,0 & 0,8 & 6,6 & 3,5 & 50,2 & 66 \\
\hline B11 & 35,0 & 1,0 & 7,2 & 3,2 & 71,0 & 98 \\
\hline B12 & 28,7 & 1,0 & 6,6 & 3,1 & 84,0 & 100 \\
\hline B13 & 39,1 & 0,9 & 6,2 & 3,1 & 59,6 & 94 \\
\hline B14 & 35,0 & 1,0 & 6,8 & 3,9 & 81,0 & 78 \\
\hline B15 & 26,7 & 1,0 & 6,2 & 3,5 & 87,0 & 73 \\
\hline B16 & 32,3 & 1,2 & 6,8 & 3,4 & 50,0 & 88 \\
\hline B17 & 45,0 & 0,9 & 6,6 & 3,3 & 71,0 & 94 \\
\hline
\end{tabular}


Apêndice F: Tabela representando parâmetros bioquímicos dos animais pertencentes ao grupo C - São Paulo - 2012

\begin{tabular}{|ccccccc|}
\hline Animal & $\begin{array}{c}\text { Uréia } \\
(\mathrm{mg} / \mathrm{dL})\end{array}$ & $\begin{array}{c}\text { Creatinina } \\
(\mathrm{mg} / \mathrm{dL})\end{array}$ & $\begin{array}{c}\text { Proteína } \\
\text { Total } \\
(\mathrm{g} / \mathrm{dL})\end{array}$ & $\begin{array}{c}\text { Albumina } \\
(\mathrm{g} / \mathrm{d} / \mathrm{L})\end{array}$ & $\begin{array}{c}\text { ALT } \\
(\mathrm{U} / \mathrm{L})\end{array}$ & $\begin{array}{c}\text { Fosfatase } \\
\text { Alcalina } \\
(\mathrm{U} / \mathrm{L})\end{array}$ \\
\hline $\mathrm{C} 1$ & 37,0 & 0,9 & 6,6 & 3,5 & 52,4 & 83 \\
\hline $\mathrm{C} 2$ & 27,3 & 1,0 & 6,5 & 3,1 & 54,1 & 60 \\
\hline $\mathrm{C} 3$ & 29,0 & 0,9 & 6,2 & 3,4 & 62,1 & 40 \\
\hline C4 & 30,0 & 0,9 & 7,2 & 3,2 & 67,9 & 65 \\
\hline C6 & 37,2 & 1,2 & 6,1 & 3,1 & 60,0 & 84 \\
\hline C7 & 30,3 & 1,0 & 6,2 & 3,5 & 49,5 & 78 \\
\hline C8 & 34,0 & 1,1 & 6,0 & 3,3 & 72,1 & 66 \\
\hline C9 & 21,0 & 1,0 & 6,8 & 3,3 & 58,3 & 50 \\
\hline C10 & 36,3 & 1,0 & 7,1 & 3,4 & 55,0 & 67 \\
\hline C11 & 39,2 & 1,0 & 6,2 & 3,5 & 61,2 & 74 \\
\hline C12 & 27,8 & 0,9 & 6,6 & 3,1 & 70,3 & 69 \\
\hline C13 & 31,5 & 1,2 & 6,2 & 3,1 & 68,6 & 62 \\
\hline C14 & 33,0 & 1,0 & 6,8 & 3,9 & 50,2 & 67 \\
\hline C15 & 27,0 & 1,0 & 6,1 & 2,9 & 70,0 & 73 \\
\hline C16 & 33,0 & 1,0 & 6,8 & 3,4 & 72,0 & 82 \\
\hline & & & & & 68,7 & 70 \\
\hline
\end{tabular}

